\title{
Membrane Stability Testing
}

by

D. T. Hobbs

Westinghouse Savannah River Company

Savannah River Site

Aiken, South Carolina 29808

This paper was prepared in connection with work done under the above contract number with the U. S. Department of Energy. By acceptance of this paper, the publisher and/or recipient acknowledges the U. S. Government's right to retain a nonexclusive, royalty-free license in and to any copyright covering this paper, along with the right to reproduce and to authorize others to reproduce all or part of the copyrighted paper. 


\section{DISCLAIMER}

This report was prepared as an account of work sponsored by an agency of the United States Government. Neither the United States Government nor any agency thereof, nor any of their employees, makes any warranty, express or implied, or assumes any legal liability or responsibility for the accuracy, completeness, or usefulness of any information, apparatus, product, or process disclosed, or represents that its use would not infringe privately owned rights. Reference herein to any specific commercial product, process, or service by trade name, trademark, manufacturer, or otherwise does not necessarily constitute or imply its endorsement, recommendation, or favoring by the United States Government or any agency thereof. The views and opinions of authors expressed herein do not necessarily state or reflect those of the United States Government or any agency thereof.

This report has been reproduced directly from the best available copy.

Available to DOE and DOE contractors from the Office of Scientific and Technical Information, P. O. Box 62, Oak Ridge, TN 37831; prices available from (423) 576-8401.

Available to the public from the National Technical Information Service, U. S. Department of Commerce, 5285 Port Royal Road, Springfield, VA 22161. 


\section{DISCLAIMER}

Portions of this document may be illegible electronic image products. Images are produced from the best available original document. 
Keywords: Caustic, Recovery, Salt Solution, Electrochemical, Waste Management

Retention time: permanent

September 30, 1997

\section{Membrane Stability Testing (U)}

Attached is the final report submitted to the Westinghouse Savannah River Company by the Electrosynthesis Company, Inc. in accordance with terms specified under contract \#AB93799N. This report details test conditions and findings from a 1000-hour stability test using a DuPont Nafion ${ }^{\text {Type }} 350$ membrane in an electrochemical salt splitting process for the recovery of caustic from alkaline salt solution. The salt solution used in the test simulates the average flowsheet composition for the Savannah River Site Decontaminated Salt Solution which is produced in the In-Tank Precipitation process and disposed in the Saltstone low-level waste disposal facility. This work was funded by the Tank Focus Area Program of the Office of Science and Technology under Technical Task Plan SR16WT41, Subtask A, "Caustic Recycle."

Key findings of the testing included: (1) successfully recovered caustic from alkaline salt solutions over a 1079-hour period at high electrically efficiency, (2) no evidence of attack of the nickel cathode and platinized-titanium anode during the test, (3) nickel is not a suitable anode material for this application, (4) aluminum-containing solids can precipitate decreasing electrical efficiency, (5) periodic cleaning of the cell with dilute acid solution restores the electrical efficiency and (6) over the 1079-hour test period, the current efficiency dropped from $>95 \%$ to approximately $90 \%$ indicating that the membrane had possibly suffered some degree of permanent damage.

$$
\text { D.T. Horhe }
$$

D. T. Hobbs, Subcontract Technical Representative

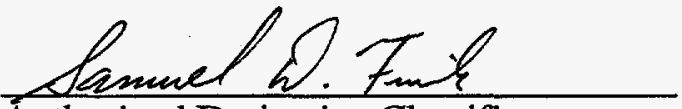

Authorized Derivative Classifier

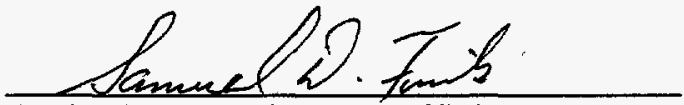

Authorized Reviewing Official

Savannah River Technology Center

Westinghouse Savannah River Company

Aiken, SC 29802

Prepared for the Department of Energy Office of Technology Development, Office of Environmental Management under Contract DE-AC09-88SR18035 
Distribution:

C. P. McGinnis, ORNL

T. Welch, ORNL

D. E. Kurath, PNNL

J. McGlynn, SAIC

E. A. Korzun, 703-A

M. G. Schwenker, 703-46A

L. M. Papouchado, 773-A

W. L. Tamosaitis, 773-A

W. E. Stevens, 773-A

S. D. Fink, 773-A

J. L. Steimke, 786-5A

D. T. Hobbs, 773-A

TIM, 773-52A 


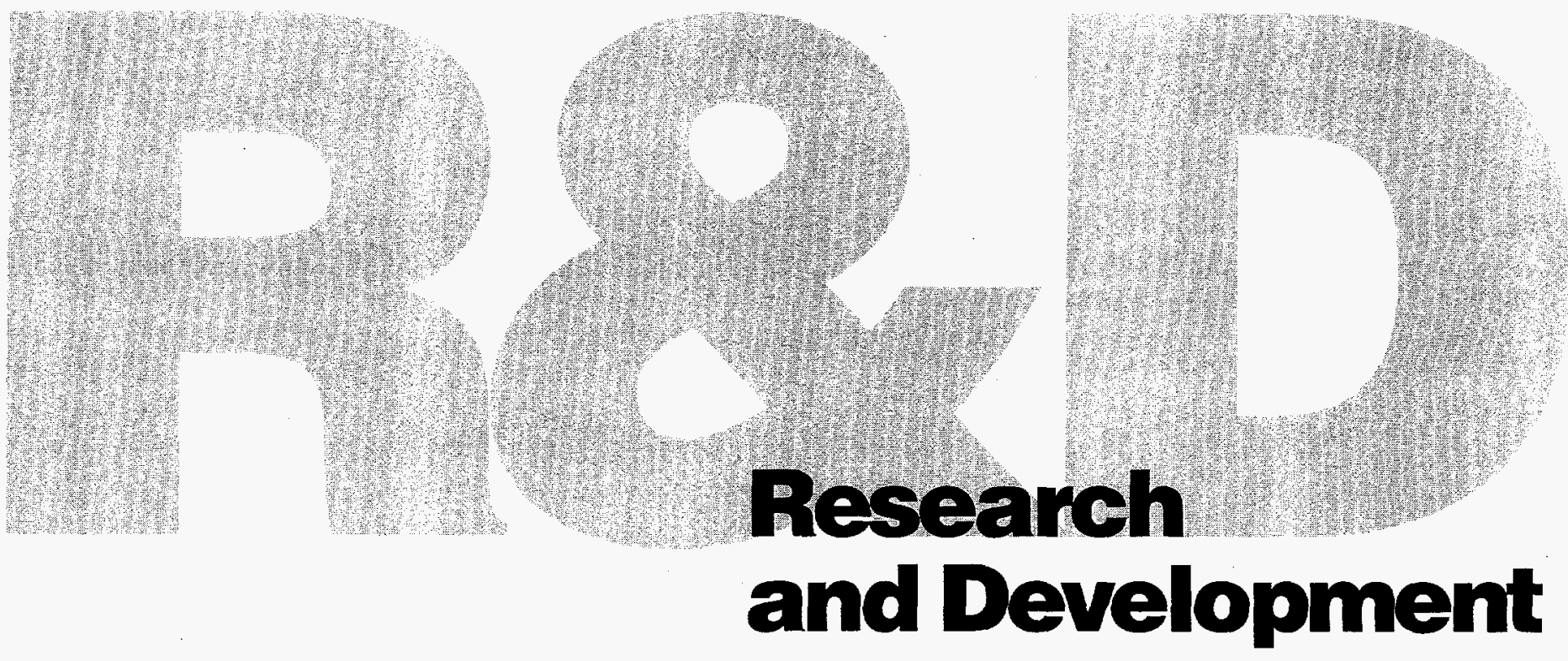

\section{"Membrane Stability Testing"}

\section{Proposal/Repont ior:}

Dr. David T. Hobbs

Westinghouse Savannah River Company

Savannah River Technology Center

Building 773-A, B-117

Aiken, SC 29808

Subcontract \#AB93799N

\section{Prepared by:}

Dr. David Genders, Vice President, R\&D

Dennis Chai, Research Chemist

August 28, 1997

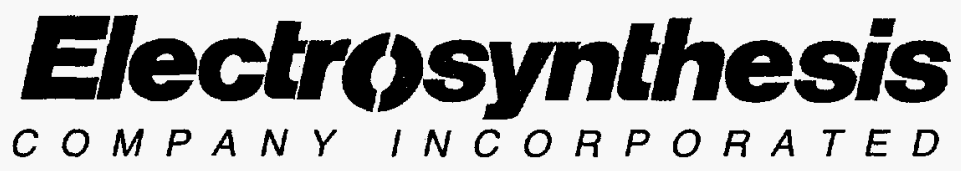

72 Ward Road, Lancaster, NY 14086-9779

Tel: 716-684-0513 - Fax: 716-684-0511

www.electrosynthesis.com 


\section{Table of Contents}

Executive Summary

Introduction 3

Experimental $\quad 4$

Process Description

Safety Interlocks $\quad 6$

Sampling And Analysis $\quad 6$

$\begin{array}{ll}\text { Acid Washing } & 7\end{array}$

Anolyte Preparation $\quad 8$

Results and Discussion 9

Nickel Anode/Cathode Configuration 9

Cell Potentials 9

Cell Disassembly and Inspection $\quad 11$

Caustic Current Efficiency 11

$\begin{array}{ll}\text { Water Transport } & 12\end{array}$

$\begin{array}{ll}\text { Platinised Titanium Anode/Nickel Cathode } & 14\end{array}$

$\begin{array}{ll}\text { Cell Potentials } & 14\end{array}$

$\begin{array}{ll}\text { Current Efficiency } & 19\end{array}$

Cell Disassembly and Inspection $\quad 21$

Conclusions and Recommendations $\quad 22$

References $\quad 24$

Appendices

1. ICI FM01 Cell

2. Schematic of Test Rig

3. Photographs of components from Nickel Anode/Cathode Run

4. Galbraith Laboratories Analytical Results

5. Photographs from Platinised Ti Anode/Ni Cathode run after 255 hours

6. Photographs from Platinised Ti Anode/Ni Cathode run at end 


\section{EXECUTIVE SUMMARY}

The Electrosynthesis Co., Inc. (ESC) has successfully demonstrated the operation of the ICI FM01 electrochemical flow cell over a 1000 hour period for the recovery of $13-14 \%$ caustic from a simulated SRS waste solution using a platinised titanium anode, nickel cathode, and a Nafion 350 membrane. At the end of the test period (1009 hrs) the anode showed no signs of deterioration in performance (based on operating potential) when compared to a new anode surface, and visual inspection revealed no obvious signs of wear. The cathode was very stable throughout the entire test period and visual inspection at the end revealed no obvious signs of wear. The membrane, however, has possibly suffered some degree of permanent damage. The damage manifests itself in the form of a slow but steady decline in caustic current efficiency, from a high of $>95 \%$ down to approximately $90 \%$ after 1079 hours. It is believed that soluble $\mathrm{Al}$ and Si species present in the anolyte were transported into the membrane where they formed complex precipitates and possibly disrupted the membrane structure.

We have also shown that nickel is unsatisfactory as an anode material in this application. Over the period that it was tested (143 hrs), the anode suffered severe corrosion, losing a significant amount of mass and also contaminating the bulk anolyte solution with soluble nickel ions. It is believed that the high current density at the anode results in depletion of caustic in the boundary layer adjacent to its surface thereby facilitating attack by corrosive species present in the anolyte such as sulfate. 


\section{INTRODUCTION}

The Electrosynthesis Co., Inc. (ESC) was contracted by the Westinghouse Savannah River Company under Subcontract \# AB93799N to investigate the long term performance and durability of cell components (anode, membrane, cathode) in an electrochemical caustic recovery process using a simulated SRC liquid waste as anolyte solution. This report details the results of two long-term studies conducted using an ICI FM01 flow cell. This cell is designed and has previously been demonstrated to scale up directly into the commercial scale ICI FM21 cell. The first study used nickel electrodes, a Nafion 350 membrane and was run for 143 hours. The second study used a platinised titanium anode, nickel cathode, a new piece of Nafion 350 membrane and was run for 1155 hours.

The reactions occurring at the anode and cathode are as follows:

$$
\begin{array}{ll}
\text { Cathode: } & 2 \mathrm{H}_{2} \mathrm{O}+2 \mathrm{e}^{-}+2 \mathrm{Na}^{+} \rightarrow \mathrm{H}_{2}+2 \mathrm{NaOH} \\
\text { Anode: } & 2 \mathrm{OH}+\mathrm{NO}_{2}^{-} \rightarrow 2 \mathrm{e}^{-}+\mathrm{H}_{2} \mathrm{O}+\mathrm{NO}_{3}^{-} \\
& 4 \mathrm{OH} \rightarrow 4 \mathrm{e}^{-}+2 \mathrm{H}_{2} \mathrm{O}+\mathrm{O}_{2} \\
& 2 \mathrm{H}_{2} \mathrm{O} \rightarrow 4 \mathrm{e}^{-}+4 \mathrm{H}^{+}+\mathrm{O}_{2}
\end{array}
$$

The reactions occurring at the anode may be any combination of the three listed. The cell voltage, electrode potentials, and membrane voltage drop were monitored continually as they provide an excellent indication of any deterioration in the cell components. The caustic current efficiency and water transport across the membrane were also measured throughout the run. The flow rate and purity of the anode gaseous products were measured as they provide an indication of the type of reaction occurring at the anode. On several occasions the anode and membrane were acid washed (usually due to increased cell voltage), either individually after opening up the cell or combined when the cell was washed in situ. Several of the washings were sent out to a commercial laboratory for 
analysis. The cell components were also visually inspected at the end of the run for signs of deterioration.

\section{EXPERIMENTAL}

\section{Process Description}

The 1000-hour run was carried out using an ICI FM01 electrochemical flow cell (Appendix 1) equipped with PTFE spacers and gaskets. The anode was initially a flat plate nickel electrode. It was subsequently replaced by a platinised titanium flat plate anode. The cathode was a flat nickel plate, and the membrane was a DuPont Nafion 350 perfluorinated cation exchange membrane. This membrane contains sulfonate ion exchange groups with a higher molecular weight polymer on the cathode side to resist hydroxide back-migration. This membrane typically operates at about $85 \%$ current efficiency for the production of $15-20 \% \mathrm{NaOH}$ in the chlor-alkali industry and is generally less sensitive to the influence of impurities ${ }^{1}$. It was pretreated by soaking in $3.5 \mathrm{M} \mathrm{NaOH}$ for several days. Turbulence promoters (PTFE) were placed on either side of the membrane for support and to prevent it from touching the electrodes. Power was supplied using a Sorenson \# DCS 20-50 DC power supply.

The anolyte loop consisted of a 1 liter glass reservoir and a March MDK-MT3 circulating pump with a Kynar head. The flow rate was monitored using a Signet Scientific Co \#3-2507.100-6V Kynar magnetic paddle wheel flow sensor coupled with an Omega \#DPF75 flow controller. The temperature was monitored using an Omega \#CN310 temperature controller coupled with a type " " thermocouple mounted in a glass thermowell in the solution reservoir. On top of the reservoir was mounted a glass condenser to remove water vapor from the gases exiting the reservoir. The gas was vented to the atmosphere. Synthetic SRS solution was circulated continuously from the bulk (200 gallon) reservoir to the glass reservoir and back at approximately 53-73 $\mathrm{ml} / \mathrm{min}$. The anode potential was monitored continually using an $\mathrm{Ag} / \mathrm{AgCl}$ reference 
electrode mounted in a separate circulation loop and connected to a Luggin probe placed at the electrode.

The catholyte loop consisted of a 2 liter glass reservoir and a magnetically coupled gear pump (\#H07144-91 motor, \#H07001-40 SS head, Cole Parmer Instrument Co.) for circulation. The flow rate was monitored using a Signet Scientific Co \#32507.100-6V Kynar magnetic paddle wheel flow sensor coupled with an Omega \#DPF78A flow controller. The temperature was monitored using an Omega \#CN310 temperature controller coupled with a type " " thermocouple mounted in a glass thermowell in the solution reservoir. On top of the reservoir was mounted a glass condenser to remove water vapor from the gas leaving the reservoir. This gas was vented to the atmosphere. Deionized water was fed continually to the catholyte reservoir to maintain the caustic strength and the product caustic overflowed to a separate collection vessel. Solution samples were also taken frequently and analyzed for caustic strength. The cathode potential was monitored continually using an $\mathrm{Ag} / \mathrm{AgCl}$ reference mounted in a separate circulation loop and connected to a Luggin probe placed at the electrode. A diagram of the test rig is shown in Appendix 2. Selected data (cell voltage, electrode potentials, membrane voltage drop, solution temperatures) were monitored and recorded continually using the Ducksoup ${ }^{\mathrm{TM}}$ Version 1.23 data acquisition software coupled with a Keithly Metrabyte DAS1401 data acquisition board. All voltage signals coming into the board were first passed through a National Instruments \#SCXI 1120 signal isolation amplifier which was connected to a \#SCXI 1000 chassis (for power) through a \#SCXI 1320 terminal block. This system filtered out AC "noise" in the signals caused by the close proximity to other electrical equipment. Other data (recirculation rates, volumes, concentrations etc were recorded on log sheets. All major electrical components of the system were connected to a Sola model \# 510 uninterruptible power supply to ensure continued operation. A summary of actual operating conditions is listed below.

Anolyte flow rate : $0.7 \mathrm{gal} / \mathrm{min}$

Catholyte flow rate : $0.7 \mathrm{gal} / \mathrm{min}$ 
Anolyte temperature : Ambient

Catholyte temperature : Ambient

Current Density : $400 \mathrm{~mA} / \mathrm{cm}^{2}$

Initial SRS solution caustic strength : $1.5 \underline{\mathrm{M}}$

Caustic concentration : $13-15 \%$

\section{Safety Interlocks}

The safety interlock system was designed to shut down the test rig in the event an unsafe condition occurred. In addition the system could be shut down manually. The unsafe conditions are as follows:

Low anolyte flowrate (set at $0.3 \mathrm{gal} / \mathrm{min}$ )

Low catholyte flowrate (set at $0.3 \mathrm{gal} / \mathrm{min}$ )

Liquid spill on floor near bulk anolyte tank

Liquid spill in drip tray under setup

If an unsafe condition occurred then the shutdown was automatically initiated with the following result:

Power supply shutdown

Anolyte circulation pump shutdown

Catholyte circulating pump shutdown

Dilution water pump (for caustic produced) shutdown

SRS soln circulation pump (from bulk reservoir) shutdown

\section{Sampling and Analysis}

Caustic solution samples were taken daily, usually over a six-hour period and analyzed for strength using the standard acid/base titration method with phenolphthalein as 
indicator. The caustic current efficiency was then calculated for that time period. The carbonate content of the caustic was also calculated from the titration using the bromocresol green indicator end point. The water transport across the membrane was calculated based on the volume of water fed to the caustic reservoir, and the volume, density, and concentration of caustic collected.

The caustic content of the anolyte along with the carbonate content was measured using the same procedure described above. The SRS solution was also analyzed periodically for anions $\left(\mathrm{NO}_{2}{ }^{-}, \mathrm{NO}_{3}{ }^{-}, \mathrm{F}, \mathrm{Cl}^{-}, \mathrm{PO}_{4}{ }^{3-}, \mathrm{SO}_{4}{ }^{2-}\right)$ using a Dionex DX 500 Ion Chromatograph equipped with an IonPac AS4A-SC analytical column, AG4A-SC guard column, CD-20 conductivity detector, GP-40 gradient pump, and controlled using the Peaknet ${ }^{\mathrm{TM}}$ software system. The catholyte solution was also frequently analyzed for these anions. The anolyte off gas flow rate was measured using a simple burette/soap solution type bubble meter. It was qualitatively analyzed on a GowMac gas chromatograph equipped with a series 550 Thermal Conductivity detector and a Hewlett Packard \#3396A integrator. Oxygen was detected on a Molecular Sieve 60/80 $6 \mathrm{ft}$ column using helium as carrier gas. The SRS solution was analyzed for silicon, aluminum, and chromium by a commercial laboratory (Galbraith Laboratories, Inc.).

\section{Acid Washing}

The anode and membrane were acid washed on several occasions throughout the run. For the first two times the cell was taken apart and the components were washed separately with $1.0 \mathrm{M} \mathrm{HCl}$. The third acid wash was performed in situ where the cell was first drained and then rinsed three times with deionized water. Then $1.0 \mathrm{M} \mathrm{HCl}$ was added to the anolyte compartment and circulated for 15 minutes. The washing was then collected and stored. The last three acid washes were also performed in situ as before with the exception that $1.0 \underline{\mathrm{M}} \mathrm{HNO}_{3}$ was used instead of $\mathrm{HCl}$. Selected acid washing samples were sent out for analysis. 


\section{Anolyte Preparation}

The SRS synthetic solution was prepared by dissolving calculated amounts of reagent grade chemicals to give $610 \mathrm{~L}$ of final solution as summarized in Table 1. The assumption was made that the caustic content of the anolyte should initially be enough to supply all the $\mathrm{Na}^{+}$needed for caustic production in the catholyte as well as to maintain sufficient alkalinity in the anolyte to avoid precipitation at the end of the run.

Table 1

\begin{tabular}{|l|c|c|c|}
\hline Element & $\begin{array}{c}\text { Initial Concentration } \\
\text { (Nickel Anode run) }\end{array}$ & $\begin{array}{c}\text { Initial Concentration } \\
\text { (Platinised Ti Anode run) }\end{array}$ & $\begin{array}{c}\text { Final Concentration } \\
\text { (Platinised Ti Anode Run) }\end{array}$ \\
\hline $\mathrm{NO}_{2}^{-}$ & $0.57 \mathrm{M}$ & $0.59 \mathrm{M}$ & $0.081 \mathrm{M}$ \\
\hline $\mathrm{NO}_{3}^{-}$ & $2.10 \mathrm{M}$ & $2.30 \mathrm{M}$ & $2.89 \mathrm{M}$ \\
\hline $\mathrm{F}$ & $0.017 \mathrm{M}$ & $0.017 \mathrm{M}$ & $0.022 \mathrm{M}$ \\
\hline $\mathrm{Cl}^{-}$ & $0.024 \mathrm{M}$ & $0.024 \mathrm{M}$ & $0.006 \mathrm{M}$ \\
\hline $\mathrm{PO}_{4}{ }^{3-}$ & $0.006 \mathrm{M}$ & $0.0072 \mathrm{M}$ & $0.148 \mathrm{M}$ \\
\hline $\mathrm{SO}_{4}{ }^{2-}$ & $0.14 \mathrm{M}$ & $0.15 \mathrm{M}$ & $0.098 \mathrm{M}$ \\
\hline $\mathrm{CO}_{3}{ }^{2-}$ & $0.17 \mathrm{M}$ & $0.12 \mathrm{M}$ & $0.69 \mathrm{M}$ \\
\hline $\mathrm{OH}^{-}$ & $1.55 \mathrm{M}$ & $1.34 \mathrm{M}$ & $57.0 \mathrm{mg} / 1$ \\
\hline $\mathrm{Si}^{4+}$ & $89.7 \mathrm{ppm}$ & $99.6 \mathrm{ppm}$ & $4.04 \mathrm{~g} / 1$ \\
\hline $\mathrm{Al}^{3+}$ & $0.319 \%$ & $0.325 \%$ & $0.185 \mathrm{mg} / 1$ \\
\hline $\mathrm{Cr}^{6+}$ & $0.011 \%$ & $0.013 \%$ & \\
\hline $\mathrm{Ni}^{6+}$ & $<0.4 \mathrm{ppm}$ & $4.6 \mathrm{ppm}$ & \\
\hline
\end{tabular}




\section{RESULTS AND DISCUSSION}

\section{Nickel Anode/Cathode Configuration}

The initial run used a cell configured with a $\mathrm{Ni}$ anode, $\mathrm{Ni}$ cathode and a Nafion 350 membrane.

\section{Cell Potentials}

The overall cell voltage consists of several components; the decomposition voltage for the reaction, anode overpotential, cathode overpotential, membrane IR, and electrolyte and structural $\mathbb{I R}$. The decomposition voltage is independent of the cell design or hardware used. The anode and cathode overpotentials represent the extra energy above the decomposition voltage needed for the reaction to proceed at a reasonable rate. The membrane, electrolyte and structural IR are resistive losses due to the passage of electricity through them and are affected by factors such as electrolyte concentration, temperature, interelectrode gap, presence of impurities etc. Figure 1 shows the voltage vs. elapsed time for the individual cell components as well as the overall cell voltage measured throughout the run.

Figure 1

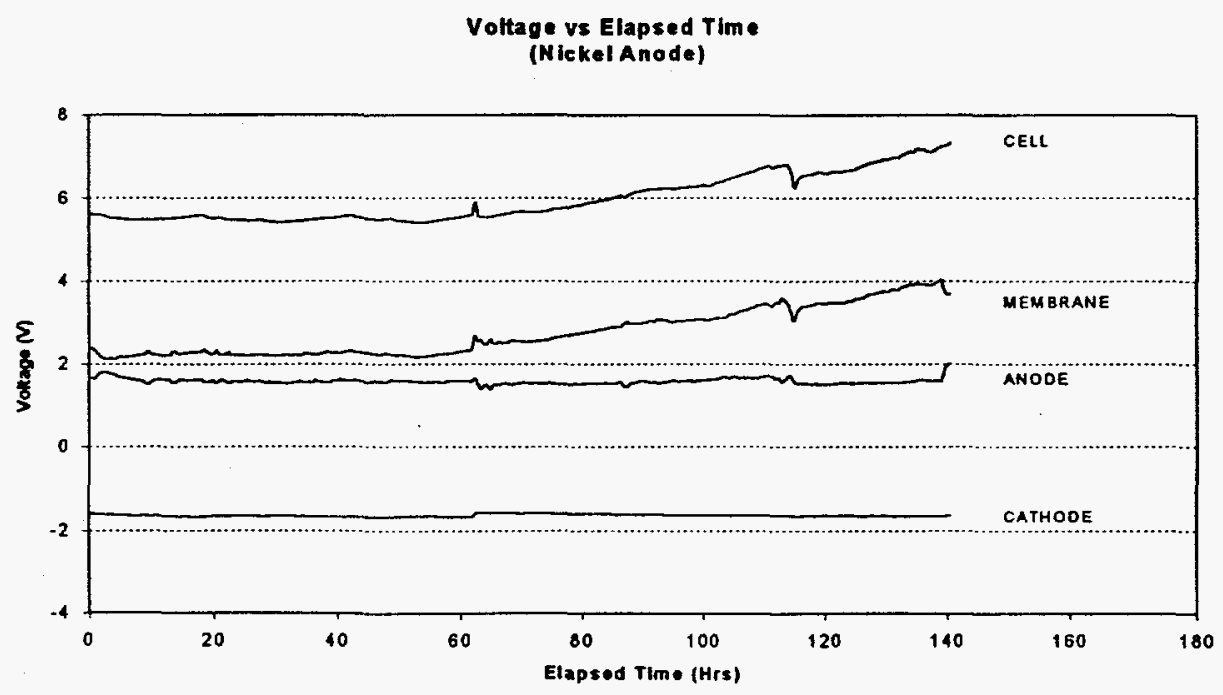


The cell was operated for 143 hours with a $\mathrm{Ni}$ anode before it was shut down due high voltage and the presence of an increasing amount of solids in the anolyte causing difficulties with maintaining a consistent flow rate. The results show that the overall cell voltage stayed constant at around 5.5-5.6V for the first 60 hours before it began to rise, reaching a high of $7.3 \mathrm{~V}$ before the run was terminated. The increase coincided with a similar increase in the membrane voltage drop. The anode potential throughout the run remained relatively constant at around 1.6 Volts vs. $\mathrm{Ag} / \mathrm{AgCl}$ reference. Measurements of the anolyte off gas flow rate (Figure 2) and composition indicate that for the duration of the run, $>95 \%$ of the current was consumed by the $\mathrm{O}_{2}$ producing reactions and very little was used for the oxidation of $\mathrm{NO}_{2}^{-}$to $\mathrm{NO}_{3}^{-}$. Frequent $\mathrm{GC}$ analysis of the off gas indicated the presence of $\mathrm{O}_{2}$ only.

Figure 2

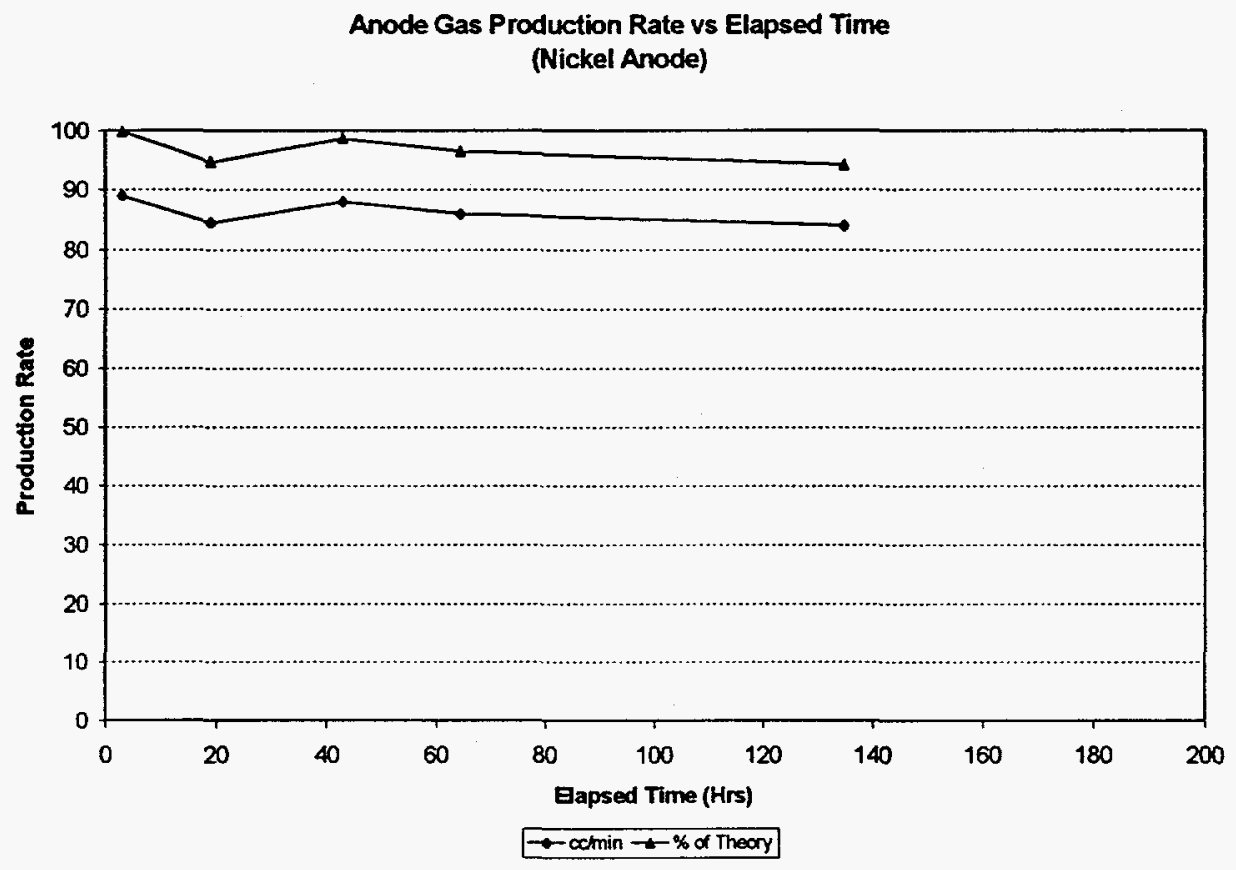

This is consistent with previous work done for Westinghouse ${ }^{2}$ which has shown that nickel anodes are very inefficient for the oxidation of $\mathrm{NO}_{2}{ }^{-}$in SRS simulants. The 
cathode potential was also very stable for the duration of the run, averaging $-1.6 \mathrm{~V}$ vs. $\mathrm{Ag} / \mathrm{AgCl}$ reference.

\section{Cell Disassembly and Inspection}

Examination of the cell components at the end of the run (see photographs Appendix 3) showed that the anode suffered severe corrosion, losing a significant amount of mass (approximately $7 \mathrm{~g}$ ). In addition, solution analyses by Galbraith Laboratories, Inc. (Appendix 4, sample B) indicate a significant increase in the nickel content of the anolyte. It is believed that the corrosion was caused by a depletion of hydroxide species in the boundary layer immediately adjacent to the anode (due to insufficient mixing at this very high current density) resulting in attack of the anode by corrosive ions such as $\mathrm{SO}_{4}{ }^{2-}$. The membrane appeared covered with a white precipitate on the anodic surface as well as within its structure.

\section{Caustic Current Efficiency}

The current efficiency for caustic production is shown in Figure 3.

Figure 3

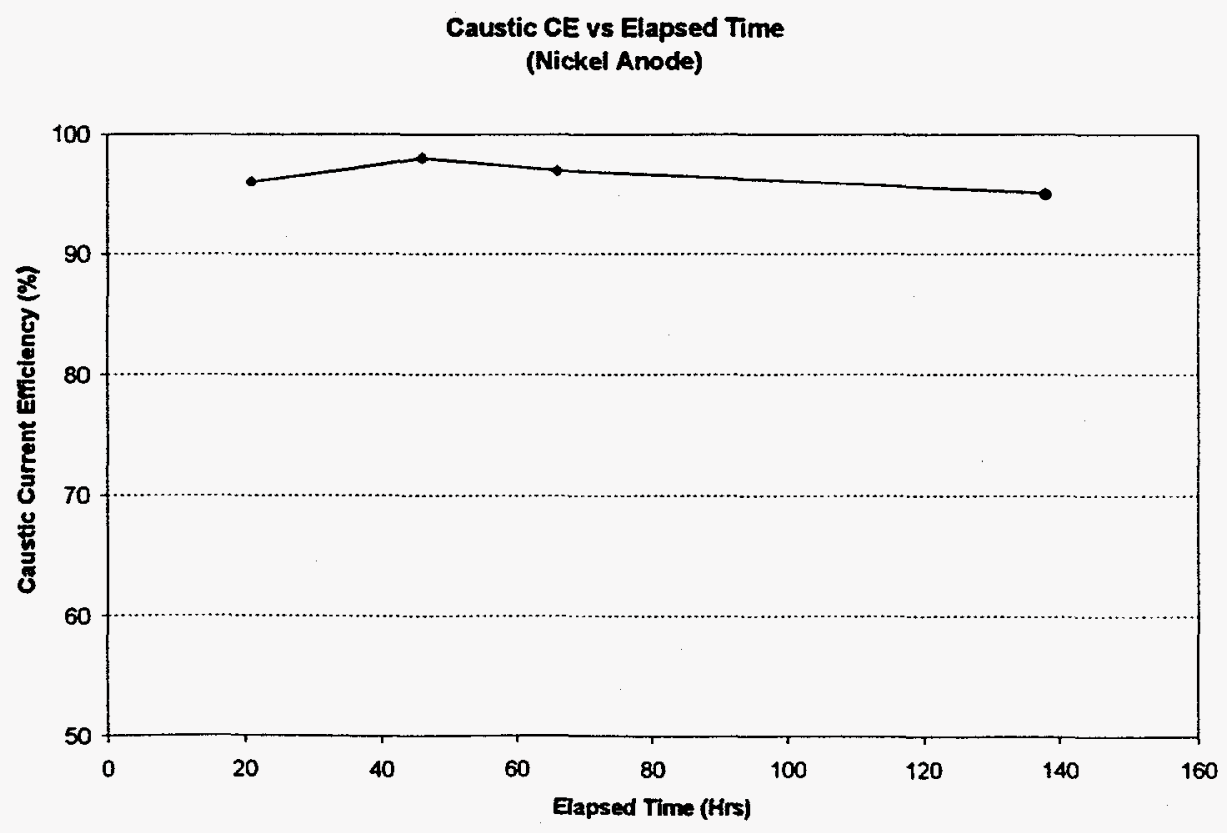


The current efficiency remained $>95 \%$, producing $13-14 \%$ caustic for the entire run (Figure 4). The current efficiency is significantly higher than is typically achieved for this type of membrane in chlor-alkali service $(85 \%)^{3}$, and may be partly due to the high salt concentration in the anolyte which could tend to dehydrate the membrane and therefore reduce the backmigration of $\mathrm{OH}^{-}$species from the catholyte compartment.

Figure 4

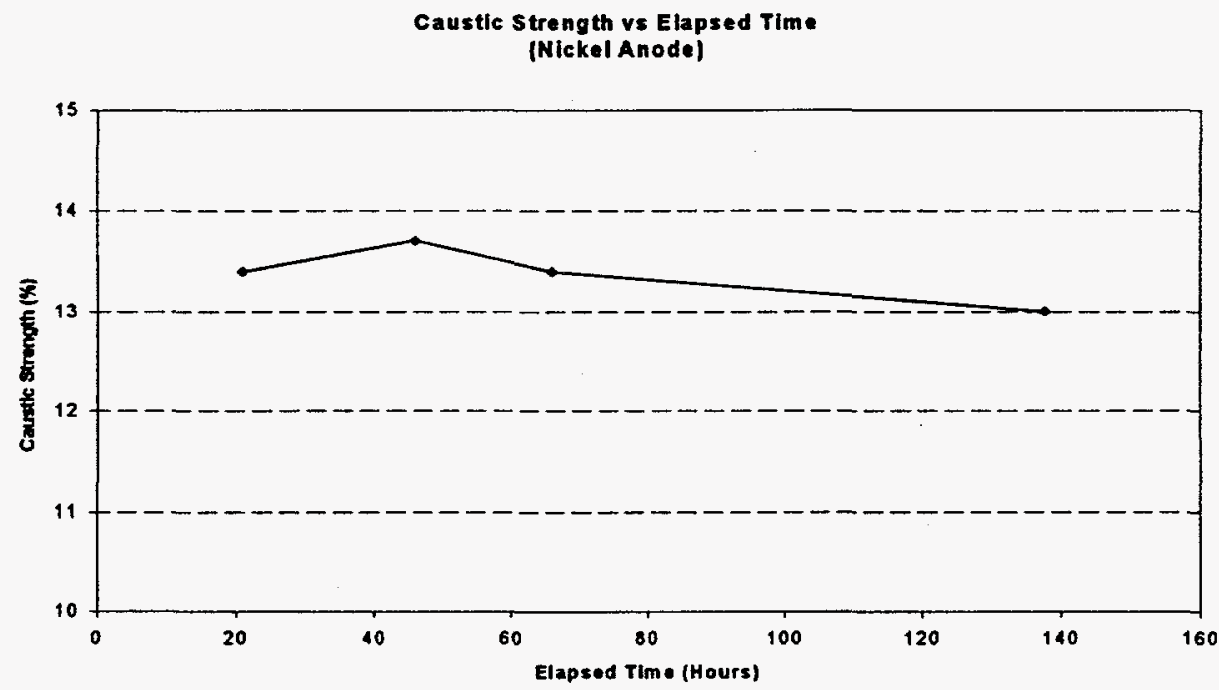

\section{Water Transport}

Water transport occurs in the cell from anolyte to catholyte because the sodium ion carries a solvation sphere with it through the membrane. Water transport is very sensitive to anolyte strength and usually decreases as anolyte strength increases ${ }^{4}$. The water transport measured for this experiment is shown in Figure 5. 
Figure 5

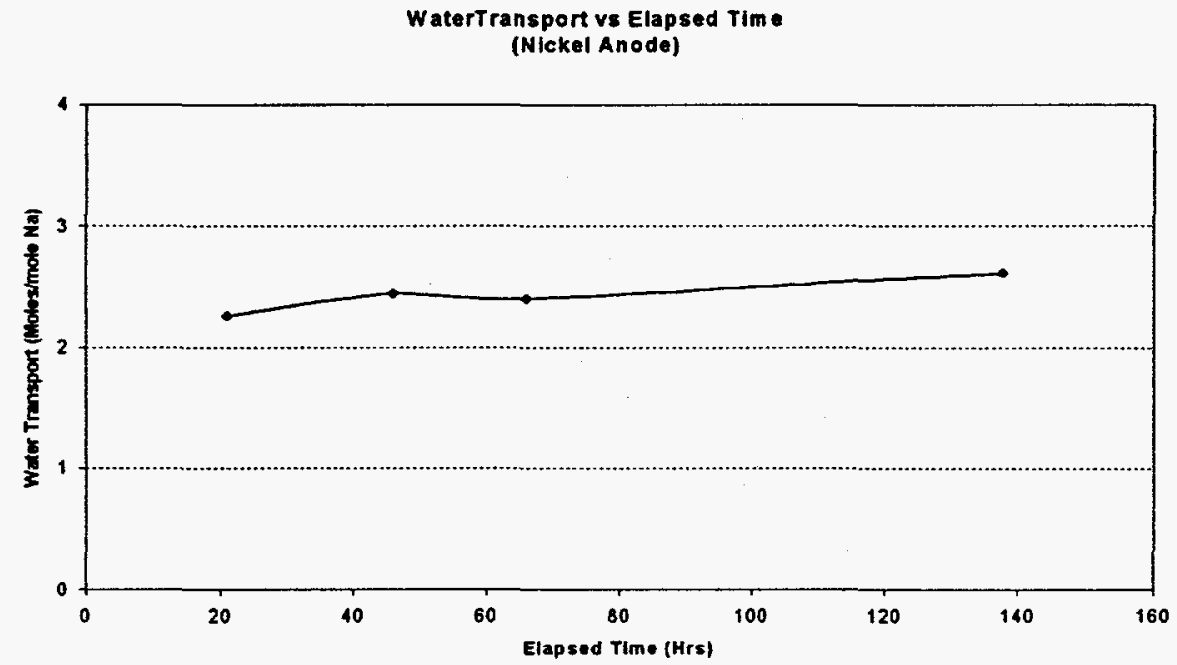

The water transport varied between $2.3-2.6 \mathrm{moles} / \mathrm{mole} \mathrm{Na}^{+}$, and although there seems to be a slight increase over time, it is likely related to experimental error rather than changing anolyte strength.

The system was run at ambient temperature and thus was sensitive to fluctuations in the external laboratory temperature. These were small and thus had only a marginal impact on the cell operation. Figure 6 shows the temperature profile for the duration of the experiment. The operating temperature in the cell typically averaged $40^{\circ} \mathrm{C}$.

Figure 6

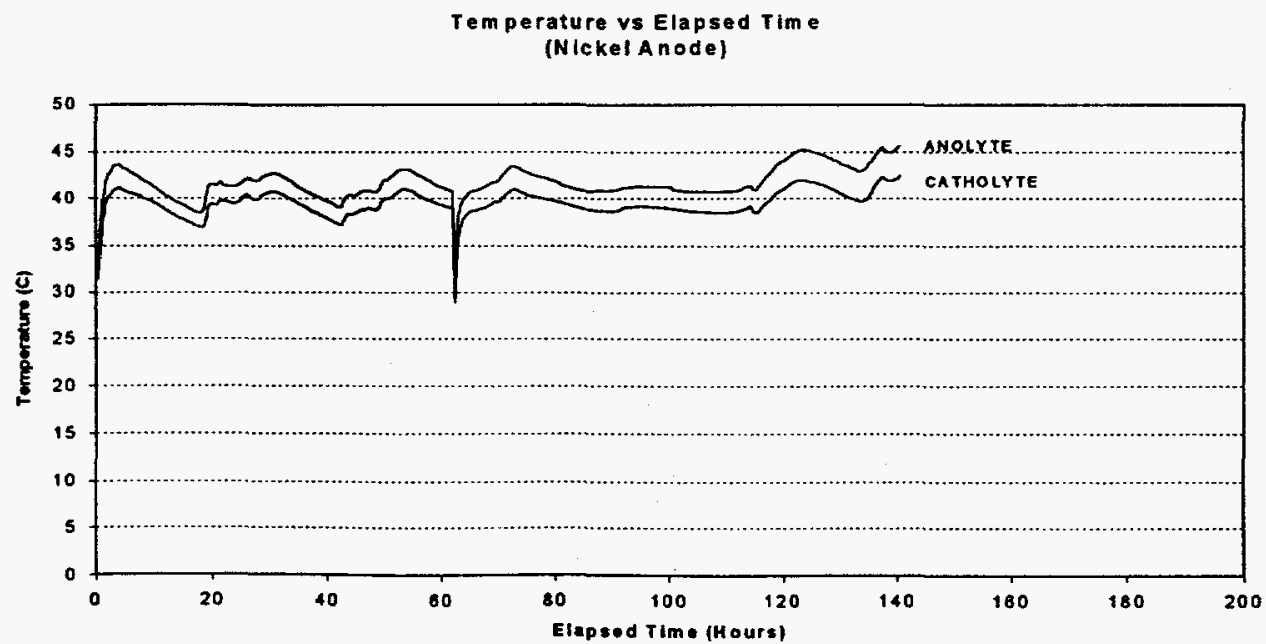




\section{Platinised Titanium Anode/Nickel Cathode Configuration}

Due to the premature failure of the $\mathrm{Ni}$ anode, a second long-term study was conducted with a platinised titanium anode. This run used the anolyte solution from the end of the first study. The composition of this solution was listed in Table 1 previously. During this study there were several events that took place to ensure continued operation of the experiment. These are listed in Table 2

Table 2

\section{List of Events}

\begin{tabular}{|c|c|c|}
\hline Event \# & $\begin{array}{c}\text { Elapsed Time } \\
\text { (Hours) }\end{array}$ & Description \\
\hline 1 & 257.5 & $\begin{array}{l}\text { Cell opened, acid washed anode and membrane } 1.0 \mathrm{M} \mathrm{HCl} \\
\text { Membrane soaked in } 4.0 \mathrm{M} \mathrm{NaOH} \text { over weekend } \\
\text { Washings analyzed }\end{array}$ \\
\hline 2 & 426 & $\begin{array}{l}\text { Cell opened, acid washed anode and membrane } 1.0 \mathrm{M} \mathrm{HCl} \\
\text { Membrane soaked in } 4.0 \mathrm{M} \mathrm{NaOH} \text { for } 1 \text { hour }\end{array}$ \\
\hline 3 & 594 & In situ acid wash with1.0M HCl \\
\hline 4 & 640.25 & $\begin{array}{l}\text { In situ acid wash with } 1.0 \mathrm{M} \mathrm{HNO}_{3} \text {. } \\
\text { Added } \mathrm{NaOH} \text { soln to bulk anolyte }\end{array}$ \\
\hline 5 & 808 & $\begin{array}{l}\text { In situ acid wash with } 1.0 \mathrm{M} \mathrm{HNO}_{3} \\
\text { Added } \mathrm{NaOH} \text { pellets to bulk anolyte } \\
\text { Washings analyzed }\end{array}$ \\
\hline 6 & 934 & $\begin{array}{l}\text { In situ acid wash with } 1.0 \underline{\mathrm{M}} \mathrm{HNO}_{3} \\
\text { Washings analyzed }\end{array}$ \\
\hline 7 & 1009 & $\begin{array}{l}\text { Cell opened, new platinised titanium anode inserted } \\
\text { Added } \mathrm{NaOH} \text { soln to bulk anolyte }\end{array}$ \\
\hline 8 & 1079 & $\begin{array}{l}\text { Cell opened, new Nafion } 350 \text { membrane inserted } \\
\text { Added } \mathrm{NaOH} \text { soln to bulk anolyte }\end{array}$ \\
\hline
\end{tabular}

\section{Cell Potentials}

The individual and combined cell potentials measured during the experiment are presented in Figure 7. The cell was operated for a total of 1155 hours before the 
experiment was ended. The cell voltage started at around $6.4 \mathrm{~V}$ and remained stable for roughly $150 \mathrm{hrs}$ before beginning to increase, reaching a high of $7.1 \mathrm{~V}$ after 257 hours when the cell was shut down (event \#1). The anode potential remained relatively constant during this time at $2.4-2.5 \mathrm{~V}$ vs. $\mathrm{Ag} / \mathrm{AgCl}$ reference. The cathode potential remained stable for the entire 1155 hours of the run at $-1.6 \mathrm{~V}$ vs. $\mathrm{Ag} / \mathrm{AgCl}$ reference. The membrane voltage however, closely mirrored that of the cell, remaining relatively flat for 150 hours before rising significantly. Upon opening up the cell, the membrane was found to have a white precipitate on its surface as well as within its structure.

\section{Figure 7}

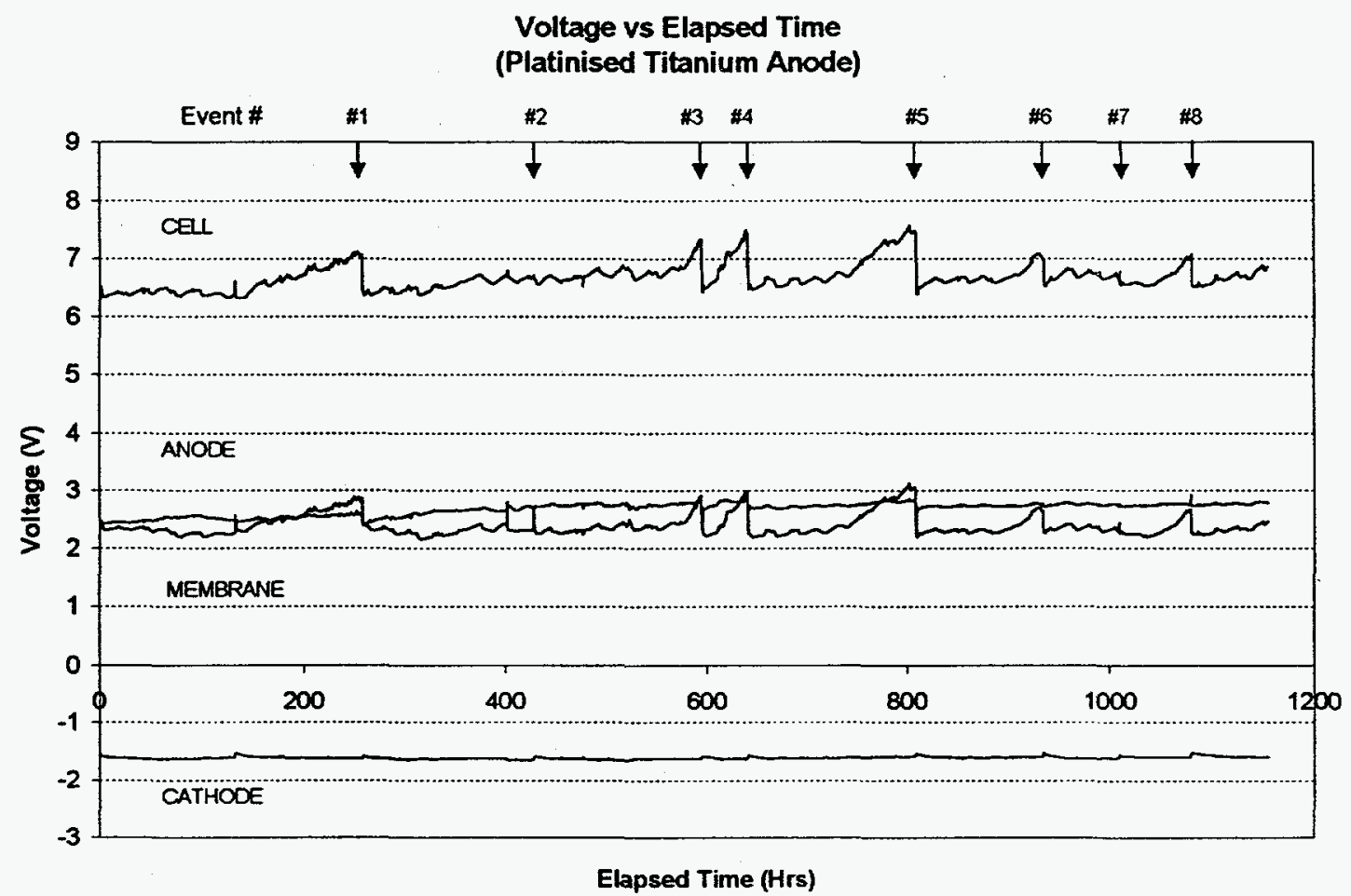

The anode was also coated with a white/yellow thin film (see photo Appendix 5). Analysis of the acid washings from the membrane and anode (Appendix 4, samples C, D) indicated elevated levels of $\mathrm{Si}$ and $\mathrm{Al}$ species as well as some $\mathrm{Ca}^{2+}$. The cell was put 
back together and restarted. Thereafter the cell was acid washed five more times (events \#2 to \#6) primarily due to increased membrane voltage, except for event \#2 where the cell was acid washed to clear the plugged anode luggin probe which had been causing erroneous readings. Each acid washing appeared to return the membrane voltage drop back to its original value. Analysis of selected acid washings (from events \#5 and \#6) also indicated elevated levels of $\mathrm{Al}$ and $\mathrm{Si}$ species (Appendix 4,samples E, F).

It has been reported ${ }^{5}$ that silica species in the anolyte can be transported into the membrane where it may combine synergistically with $\mathrm{Ca}$ and $\mathrm{Al}$ species to form precipitates, which permanently damage the membrane structure. This movement is believed to be facilitated by the water transport ${ }^{6}$ occurring with the $\mathrm{Na}^{+}$ions and ultimately results in a reduction of the membrane lifetime. Established maximums as low as $10 \mathrm{ppm}^{7}$ as $\mathrm{SiO}_{2}$ have been reported in chlor-alkali applications. (Note that these levels have been established for the bilayer membranes containing carboxylate polymer. It is known that these membrane structures are more sensitive to impurities than the 300 series membranes.)

The anode potential increased slowly but consistently from $2.4 \mathrm{~V}$ to $2.7 \mathrm{~V}$ vs. $\mathrm{Ag} / \mathrm{AgCl}$ reference over the 1009 hours that it was used in the cell. This increase is likely due to the changing nature of the reactions occurring at the anode. The off gas produced at the anode provides an excellent indication of what reactions are occurring there. Measurements of the flow rate were taken throughout the run. The results are presented in Figure 8.

These results show that for the first 650 hours, $40 \%$ or less of the current is being consumed by the $\mathrm{O}_{2}$ evolving reactions, with the rest being used to oxidize $\mathrm{NO}_{2}^{-}$to $\mathrm{NO}_{3}{ }^{-}$. Frequent $\mathrm{GC}$ analysis of the off gas indicated the presence of $\mathrm{O}_{2}$ only. Analysis of the bulk anolyte (Figure 9) during the run showed a steady decrease in the $\mathrm{NO}_{2}{ }^{-}$content and a corresponding increase in the $\mathrm{NO}_{3}{ }^{-}$content. Thereafter the off gas production rate increases until the end of the run (1009 hours) when $68 \%$ of the current was consumed by the $\mathrm{O}_{2}$ producing reaction. The almost instantaneous increases in off gas flow rates 
Figure 8

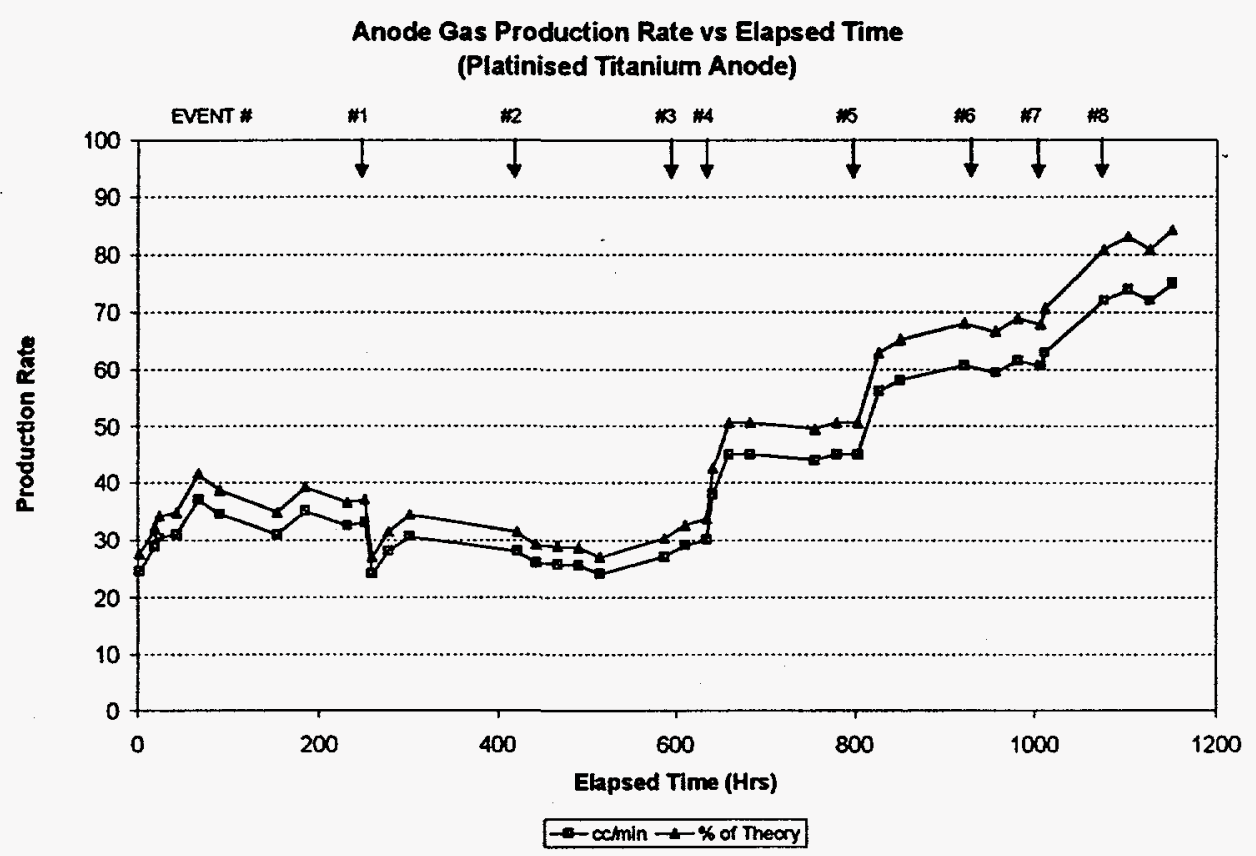

Figure 9

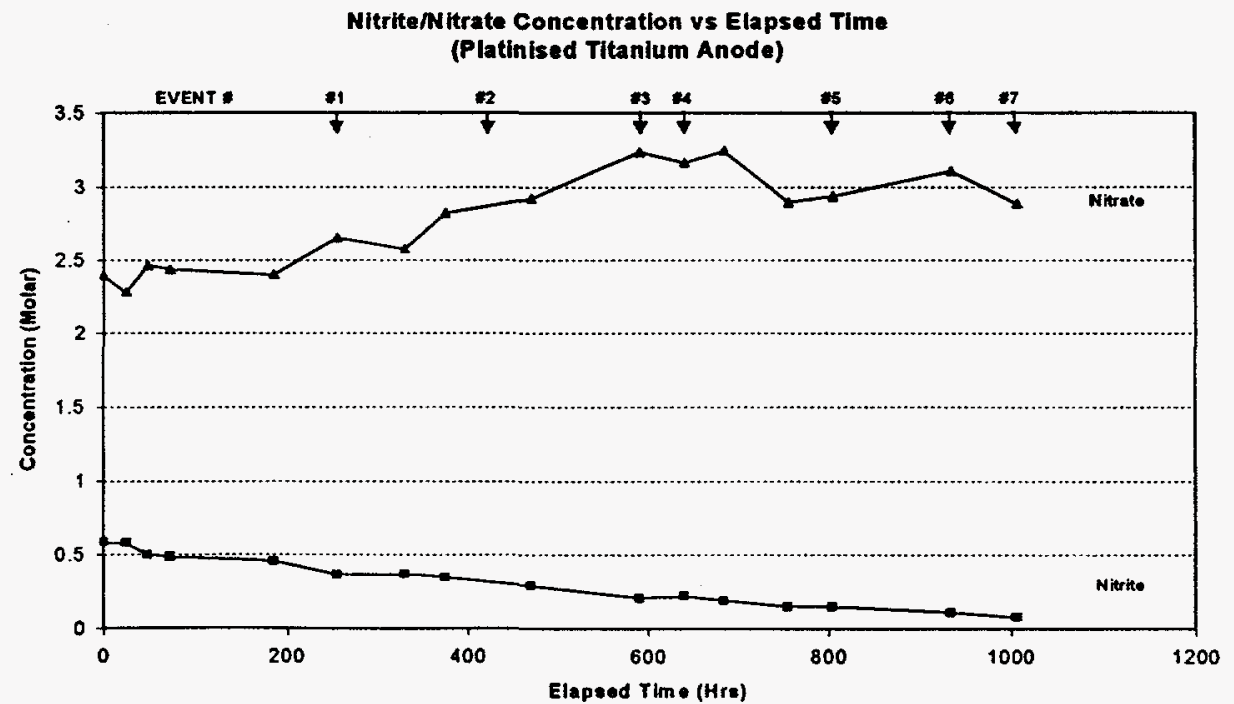


observed after events \#4, \#5, and \#7 are likely due to the caustic added at those times, making conditions more favorable for oxygen evolution. A summary of the caustic additions to the bulk anolyte is shown in Figure 10.

Figure 10

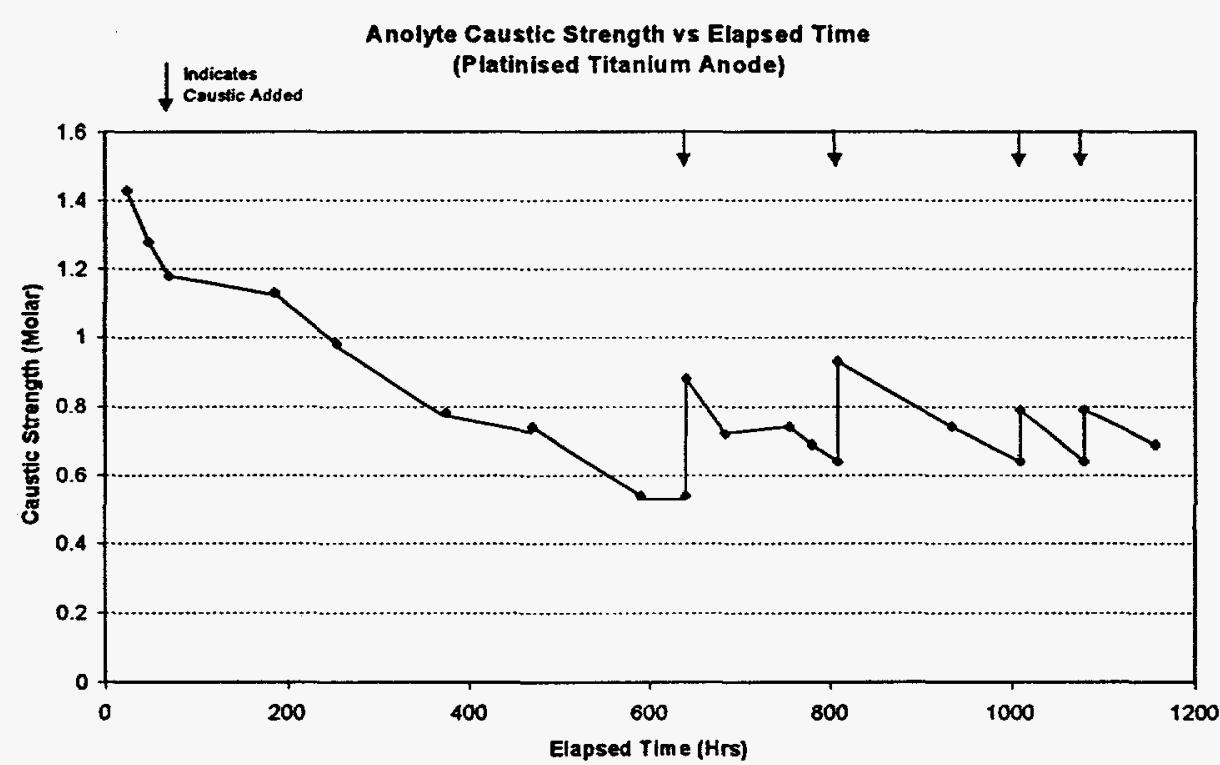

It was necessary to add caustic to the bulk anolyte on several occasions to prevent precipitation from occurring. Precipitation was initially observed after approximately 594

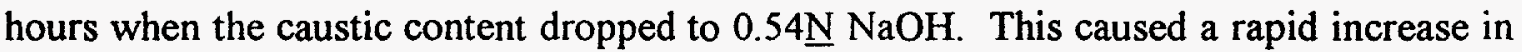
cell voltage and necessitated an acid wash (Event \#4) shortly after the previous one. Subsequently the caustic content was maintained above $0.6 \mathrm{~N} \mathrm{NaOH}$.

After 1009 hours (event \#7) the anode was reversed so that the unused side was now exposed to the solution. The cell was run a further 146 hours with this anode surface to establish a new baseline with the changed anolyte composition. The potential profile for the new anode surface was almost identical to that of the used surface, indicating that there was no apparent damage to the anode over the 1009 hours that it was tested. 


\section{Current Efficiency}

The caustic current efficiency measured during the run is shown in Figure 12 and the caustic strength produced is shown in Figure 11.

\section{Figure 11}

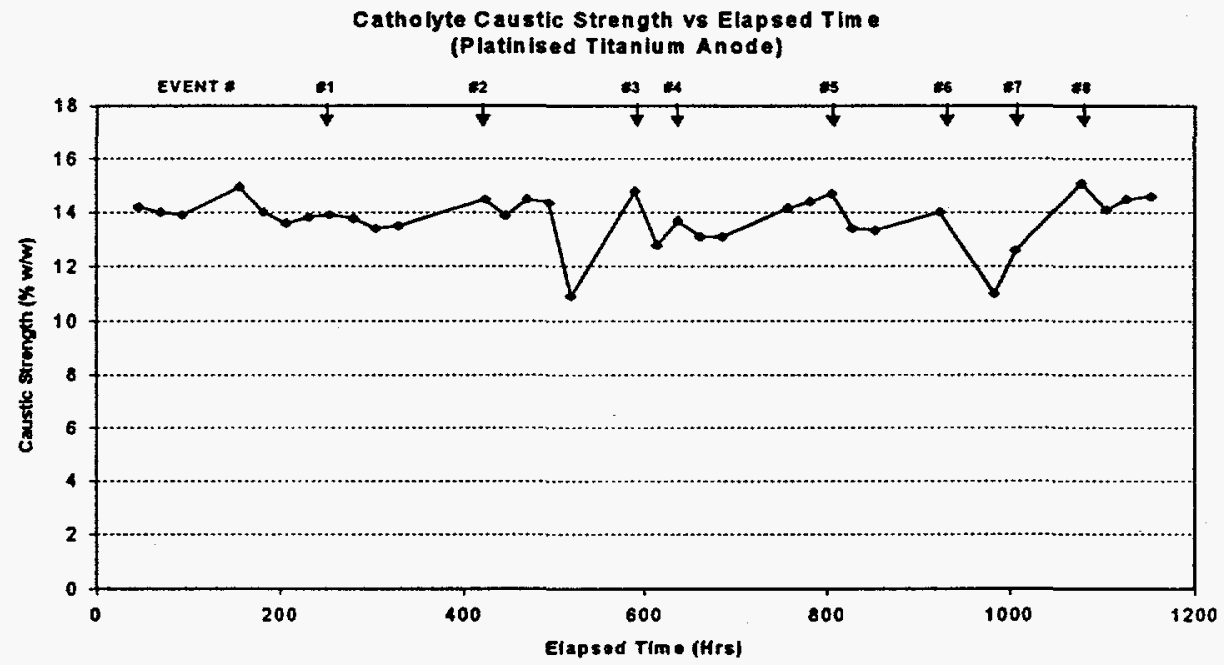

Figure 12

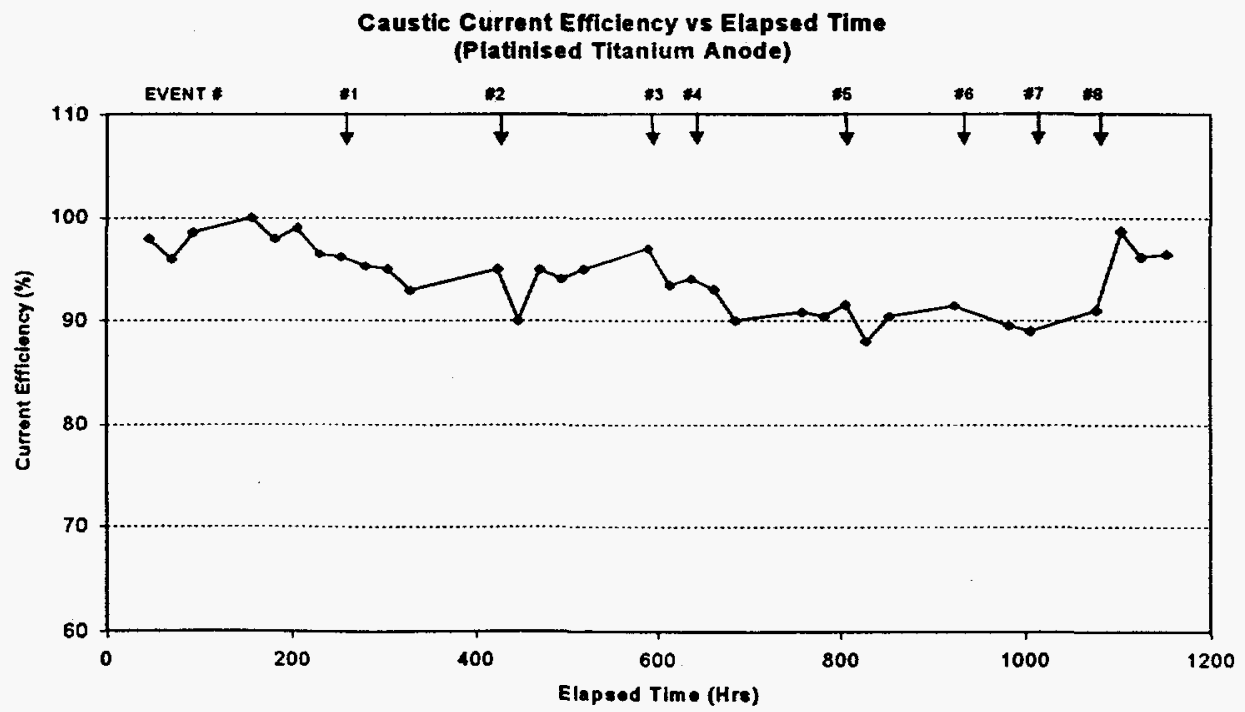




\section{Figure 13}

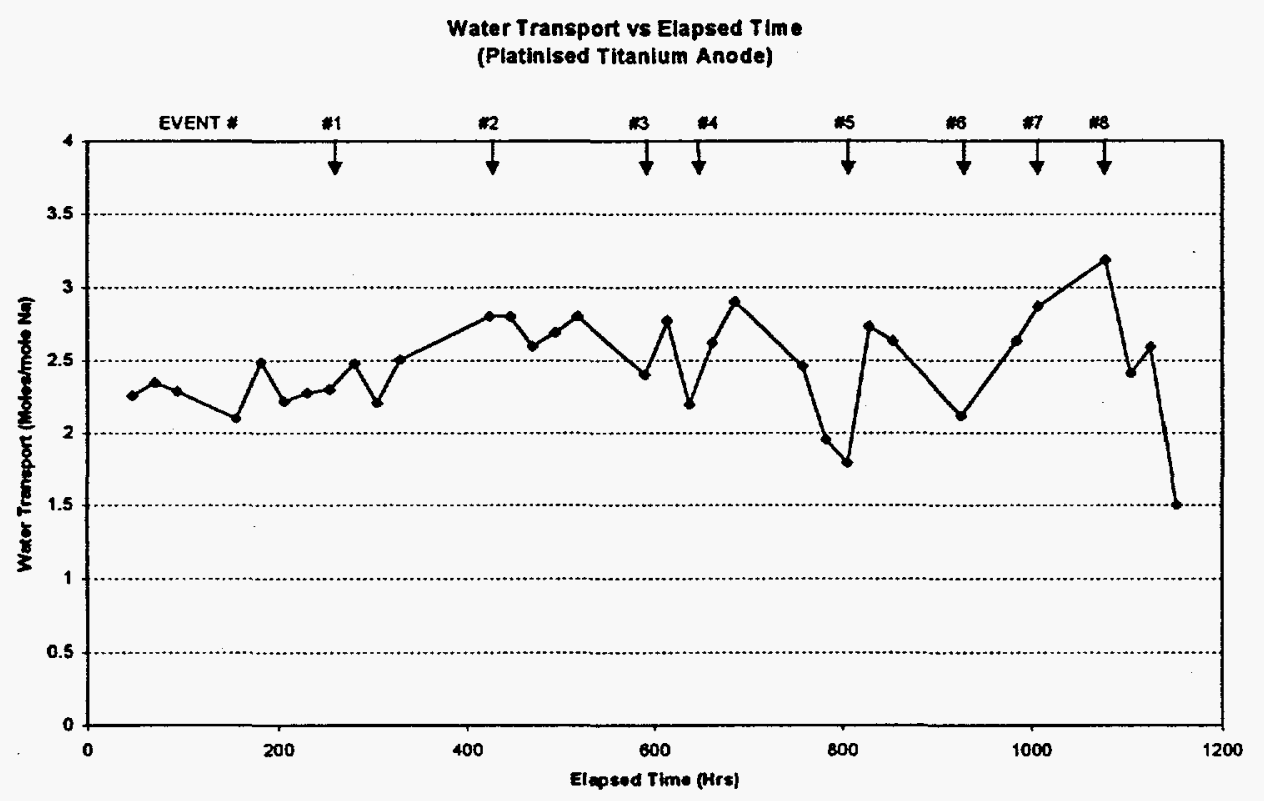

The results indicate that current efficiencies were quite high for roughly the first 200 hours, producing approximately $14 \% \mathrm{NaOH}$ at over $95 \%$. However, the efficiency declined slowly, finally averaging around $90 \%$. After1079 hours the Nafion 350 membrane was replaced to determine the effect on current efficiency (event \#8). This resulted in an immediate and sustained increase in the current efficiencies back to $>95 \%$, as was measured initially. It is believed that the used membrane has suffered some degree of permanent damage, likely due to the precipitation of $\mathrm{Si}$ and $\mathrm{Al}$ species within the membrane referred to previously.

The water transport across the membrane is shown in Figure 13. For the majority of time the water transport ranged between $2-3$ moles $/ \mathrm{mole}^{+}{ }^{+}$. This is similar to that observed previously. Several analyses by ion chromatography of the caustic produced over the 1000-hour run indicated that $\mathrm{NO}_{3}{ }^{-}$was the only detectable impurity present. The highest concentration obtained was $0.6 \mathrm{mM}$ and the average was $0.4 \mathrm{mM}$. These levels are 
comparable to the $\mathrm{Cl}^{-}$levels in caustic normally seen in the conventional chlor-alkali process $^{8}$. It is possible to calculate a maximum diffusion coefficient of $3.6 \mathrm{E}^{-13} \mathrm{~m}^{2} / \mathrm{sec}$ from this data, which is quite low when compared to reported diffusion rates of other similar anions through perfluorosulfonic acid type membranes'.

The operating temperature of the system throughout the run was very similar. to that observed earlier and averaged around $40^{\circ} \mathrm{C}$ (Figure 14).

\section{Cell Disassembly and Inspection.}

Examination of the cell components after they were removed from the cell (see photographs Appendix 6) showed that the anode appeared physically unchanged except for a slight surface discoloration. The cathode surface also appeared to have a dark discoloration, but this was easily removed by acid washing with dilute acid. There was no apparent physical damage to the cathode. The membrane appeared to have a white deposit both on its surface as well as within its structure. Acid washing of the membrane with dilute nitric acid was successful in removing all of the deposit from the surface and some from within the structure.

Figure 14

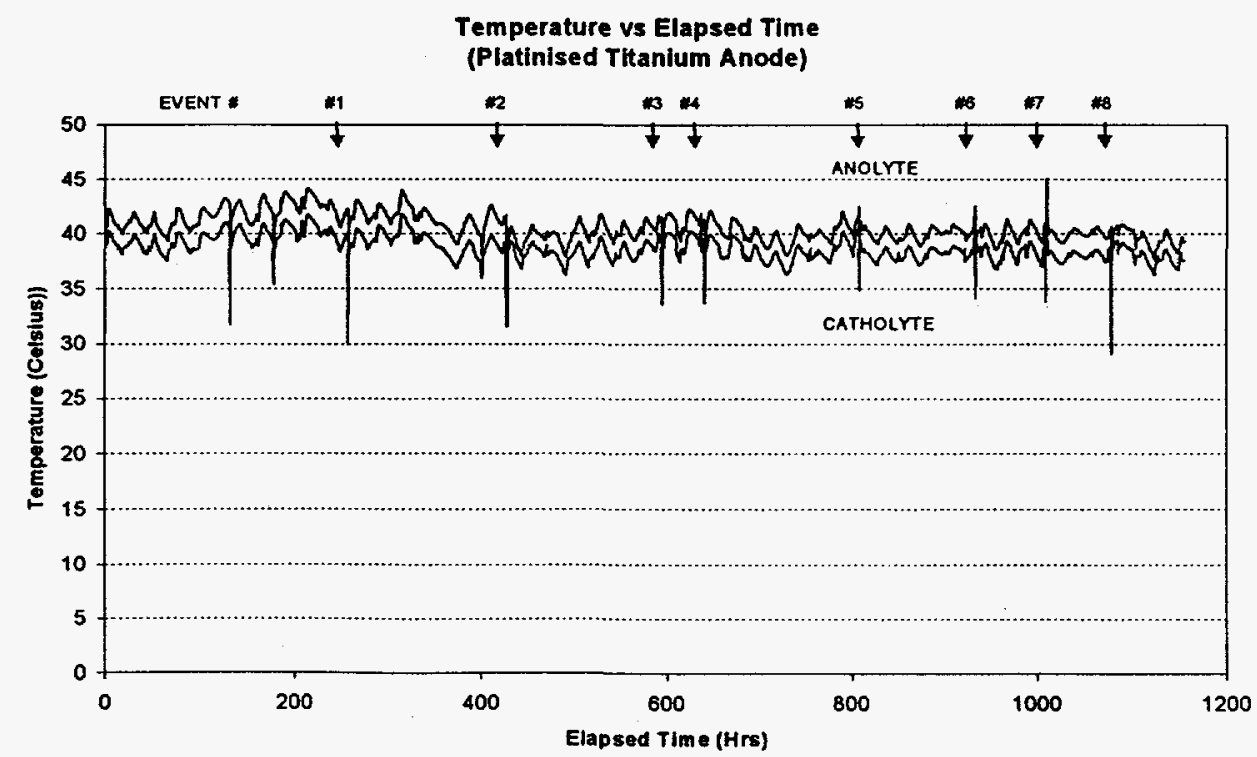




\section{CONCLUSIONS AND RECOMMENDATIONS}

We have successfully demonstrated that caustic can be recovered from a simulated SRS liquid waste using an ICI FMO1 electrochemical cell equipped with a platinised titanium anode, Nafion 350 membrane, and nickel cathode. Over the period tested (1009 hrs), the cell consistently produced an average $13.8 \% \mathrm{NaOH}$ solution of high purity. The performance (voltage profile) of the platinised titanium anode appeared unchanged after the run when compared to the performance of a new (unused) surface. The caustic current efficiency began at $>95 \%$ efficiency but dropped slowly down to $90 \%$ by the end of the run. Comparison of the used membrane performance with that of a new piece indicates that there has been some permanent damage to the membrane. This is likely due to the precipitation of $\mathrm{Al}$ and $\mathrm{Si}$ species which react synergistically to form complex precipitates within the membrane structure, thereby disrupting it. While it has been shown that the membrane performance can be partly restored by acid washing, it is not known how much further the current efficiency will drop at even longer operating times. No apparent damage to the cathode was noted.

We have also shown that nickel is an unacceptable anode material in this application. During the 143 hours that the cell was run with a nickel anode, severe degradation of its surface occurred, causing precipitation of nickel containing solids in the anolyte reservoir that necessitated stopping the run. The anolyte was also contaminated with soluble nickel species, which in high enough quantities are also known to affect membrane performance ${ }^{10}$. It is believed that the degradation is a result of the high current density in combination with the presence of corrosive species such as $\mathrm{SO}_{4}{ }^{-2}$ in the anolyte, facilitating the attack on the anode surface. It is possible that the deterioration in membrane performance (due to $\mathrm{Al} / \mathrm{Si}$ precipitates) could be reduced through the following approaches: 
(a) Increase the amount of water in the membrane. This could be achieved by either diluting the catholyte or by using a lower equivalent weight polymer. The latter would likely affect the current efficiency of the process.

(b) Reduce the current density. This should prolong the onset of precipitation in the membrane.

(c) Increase the temperature. This may increase the solubility of the $\mathrm{Si}$ and $\mathrm{Al}$ species in the membrane.

(d) Use a different membrane.

Clearly the tradeoff between membrane life, current efficiency and operating voltage will need to be assessed as a function of overall economics. 


\section{REFERENCES}

1. Seko, M. et al, "Recent developments in ion exchange membranes for chlor-alkali electrolysis", Modern Chlor-alkali Technology, 3, 188 (ed. Kevin Wall), Ellis Horwood Publishers, 1986.

2. D. Chai, D. Hartsough, D. Genders, Phase III Final Report " Electrochemical Processing of Hanford and SRS Waste Simulants using an ICI FM21-SP Pilot Scale Flow Cell.", Electrosynthesis Co., Inc., Subcontract \# AA82238N, September14, 1995.

3. Maloney, Daniel. E, "Fluorocarbon membranes for the chlor-alkali industry", Modern Chlor-alkali Technology, 1, 174 (ed. M.O Coulter), Ellis Horwood Publishers, 1980.

4. Keating, J.T, "Understanding Membrane Operating Conditions", Modern Chlor-alkali Technology, 5, 75 (ed. T.C Wellington), Elsevier Applied Science, 1986.

5. Bissot, T.C, "Mechanism of Silica Damage to Chlor-alkali Membranes", Proceedings of the Symposium on Diaphragms, Separators, and Ion Exchange Membranes, (ed. Van Zee et al) Vol 86-13, pg 46.

6. F. Hine, T. Ohtsuka, M. Hayashi, K. Suzuki, "Effect of silicate on the membrane-type chlor-alkali cell", J Applied Electrochemistry, 21, 784 (1991).

7. Minz, F.R, "The Importance of Electrolyte Quality to Membrane Chlor-alkali Cells: How to Control Various Impurities", Modern Chlor-alkali Technology, 6, 215 (ed. R.W Curry), Royal Society for Chemistry, Cambridge, 1995.

8. Baucom, E.I, "Nafion Membranes for the 1990's", Modern Chlor-alkali Technology, 5, 137 (ed. T.C Wellington), Elsevier Applied Science, 1992.

9. A. Herrera, H.L Yeager, "Halide and Sulfide Ion Diffusion in Nafion Membranes", J Electrochemical Society, Vol 34, No.10, 2449 (Oct. 1987).

10. Keating, J.T, Behling, K.J, "Brine, Impurities, and membrane chlor-alkali cell performance", Modern Chlor-alkali Technology, 4, 130 (ed. N.M Prout, J.S Moorehouse), Elsevier Applied Science, 1990. 
Appendix 1

ICI FM01 Cell 


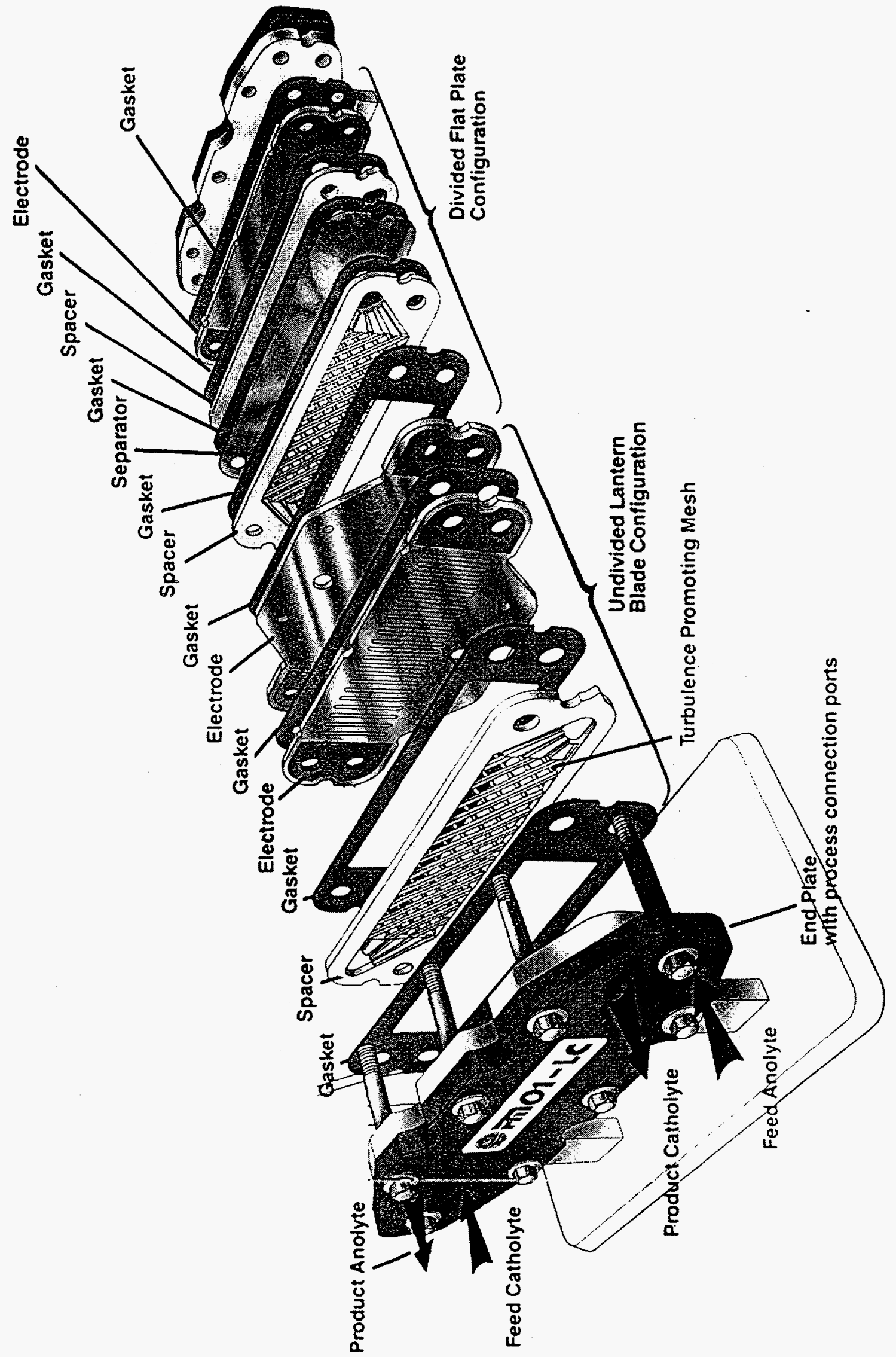


Appendix 2

Schematic of Test Rig 


\section{Appendix 3}

Photographs of Components from Nickel Anode/Cathode Run 

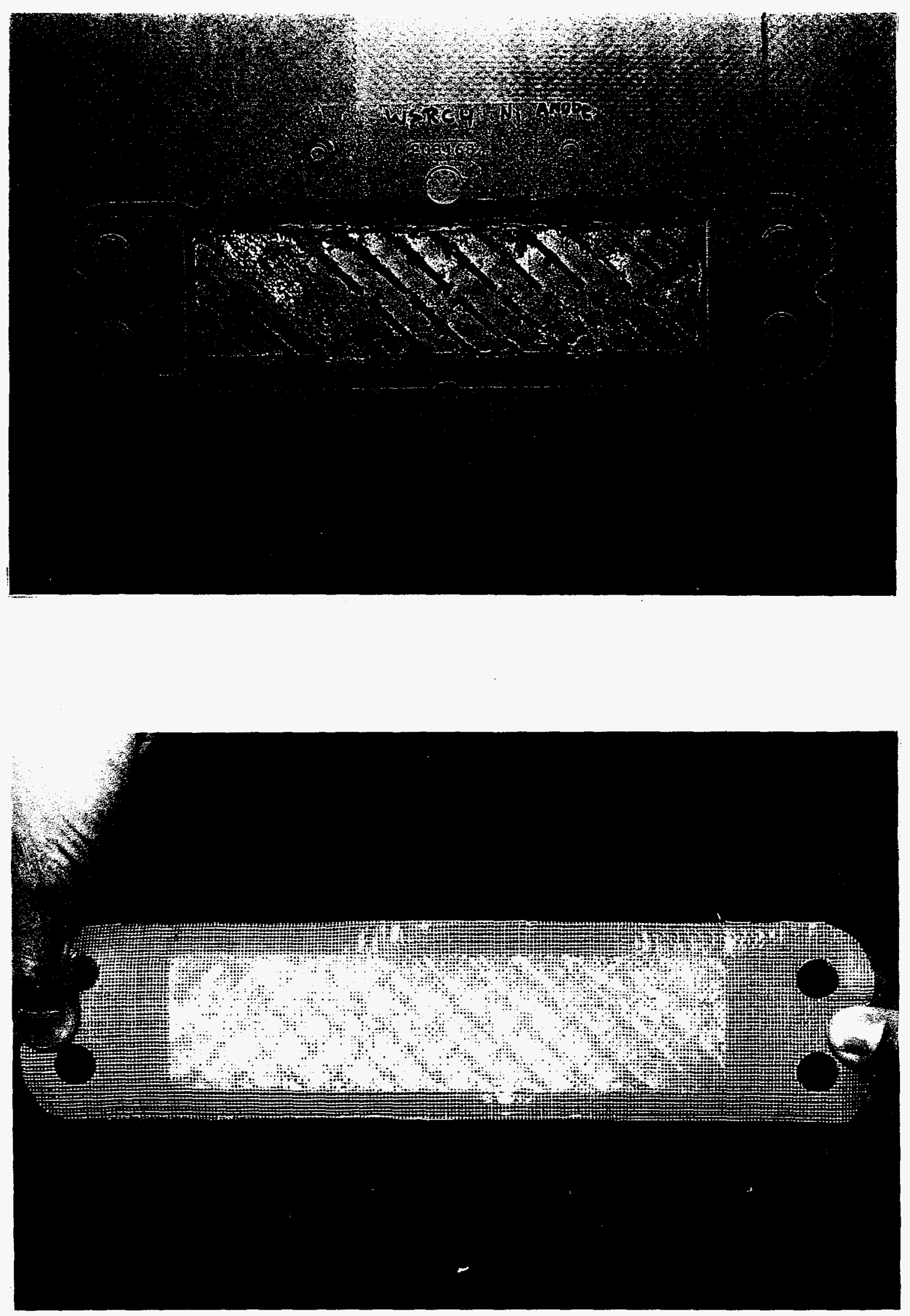


\title{
Appendix 4
}

Galbraith Laboratories Analytical Results.

\author{
Summary Table
}

\begin{tabular}{|c|l|}
\hline Sample ID\# & \multicolumn{1}{|c|}{ Description } \\
\hline A & Initial Bulk Anolyte Soln (Ni Anode Run) \\
\hline B & Initial Bulk Anolyte Soln (Platinised Ti Anode Run) \\
\hline C & Membrane Acid Washing (255 Hrs Elapsed) \\
\hline D & Electrode Acid Washing (255 Hrs Elapsed) \\
\hline E & Acid Washing (808 Hrs Elapsed) \\
\hline F & Acid Washing (934 Hrs Elapsed) \\
\hline G & Bulk Anolyte (1009 Hrs Elapsed) \\
\hline
\end{tabular}




\section{LABORATORY REPORT}

Dennis Chai

Electrosynthesis Co

72 Ward Rd

Lancaster NY 14086
Report Date: $\quad \quad 07 / 14 / 97$

Sample Received: $\quad$ 06/12/97

Purchase Order \#: $\quad$ WSRC461197DC

Fax Number: $\quad$ 716-684-0511

\begin{tabular}{|lllll|}
\hline SAMPLE ID & LAB ID & ANALYSIS & \multicolumn{2}{c|}{ RESULTS } \\
\hline A & U-2076 & Aluminum & 0.319 & $\%$ \\
& & Silicon & 89.7 & ppm \\
& Nickel & $<0.4$ & ppm \\
& Chromium & 0.011 & $\%$ \\
\hline B & Aluminum & 0.325 & $\%$ \\
& U-2077 & Silicon & 99.6 & $\mathrm{ppm}$ \\
& & Nickel & 4.6 & $\mathrm{ppm}$ \\
& & Chromium & 0.013 & $\%$ \\
\hline
\end{tabular}

BDS:sc

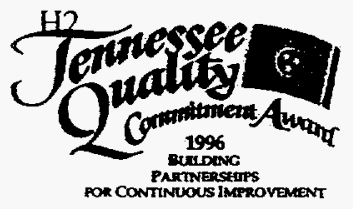

U.S. Mail: P.O. Box 51610 - Knoxville, TN 37950-1610

Other Carriers: 2323 Sycamore Drive . Knoxville, TN 37921-1750 Tel: (423) 546-1335 ․ Fax: (423) 546-7209 


\section{GALBRAITH ${ }^{\circledR}$ LABORATORIES, INC.}

Accuracy with speed - since 1950

\section{LABORATORY REPORT}

Dennis Chai

Electrosynthesis Co

72 Ward Rd

Lancaster NY 14086
Report Date: $\quad$ 07/28/97

Sample Received: $\quad$ 07/02/97

Purchase Order \#: $\quad$ WSRC470197DC

Fax Number: 716-684-0511

\begin{tabular}{|lllll|}
\hline SAMPLE ID & LAB ID & ANALYSIS & RESULTS & \\
\hline \multirow{2}{*}{ C } & U-4782 & Aluminum & 327 & $\mathrm{mg} / 1$ \\
& & Silicon & 284 & $\mathrm{mg} / 1$ \\
& & Calcium & 38 & $\mathrm{mg} / 1$ \\
\hline $\mathrm{D}$ & $\mathrm{U}-4783$ & Aluminum & 78 & $\mathrm{mg} / 1$ \\
& & Silicon & 68 & $\mathrm{mg} / 1$ \\
& & Calcium & 6 & $\mathrm{mg} / \mathrm{l}$ \\
\hline
\end{tabular}

ICP:le

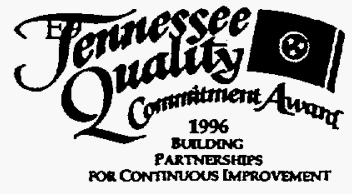

U.S. Mail: P.O. Box 51610 - Knoxville, TN 37950-1610

Other Carriers: 2323 Sycamore Drive - Knoxville, TN 37921-1750

Tel: (423) 546-1335 - Fax: (423) 546-7209 


\section{GALBRAITH ${ }^{\otimes}$ LABORATORIES, INC.}

Accuracy with speed - since 1950

\section{LABORATORY REPORT}

Dennis Chai

Electrosynthesis Co

72 Ward Rd

Lancaster NY 14086
Report Date:
$08 / 07 / 97$
Sample Received:
08/05/97
Purchase Order \#: $\quad$ WSRC480497DC
Fax Number:
716-684-0511

\begin{tabular}{|c|c|c|c|c|}
\hline SAMPLE ID & LAB ID & ANALYSIS & RESULT & \\
\hline \multirow[t]{2}{*}{$\mathrm{E}$} & U-8700 & Aluminum & 400 & $\mathrm{mg} / \mathrm{l}$ \\
\hline & & Silicon & 353 & $\mathrm{mg} / \mathrm{l}$ \\
\hline \multirow[t]{2}{*}{$\mathbf{F}$} & U-8701 & Aluminum & 459 & $\mathrm{mg} / \mathrm{l}$ \\
\hline & & Silicon & 368 & $\mathrm{mg} / \mathrm{l}$ \\
\hline \multirow[t]{3}{*}{ G } & U-8702 & Aluminum & 4040 & $\mathrm{mg} / \mathrm{l}$ \\
\hline & & Silicon & 57 & $\mathrm{mg} / \mathrm{l}$ \\
\hline & & Chromium & 185 & $\mathrm{mg} / \mathrm{l}$ \\
\hline
\end{tabular}

CB:le

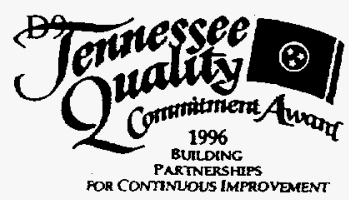

U.S. Mail: P.O. Box 51610 - Knoxville, TN 37950-1610

Other Carriers: 2323 Sycamore Drive . Knoxville, TN 37921-1750

Tel: (423) 546-1335 Fax: (423) 546-7209 
Appendix 5

Photographs from Platinised Ti Anode/ Ni Cathode Run after 255 hours. 


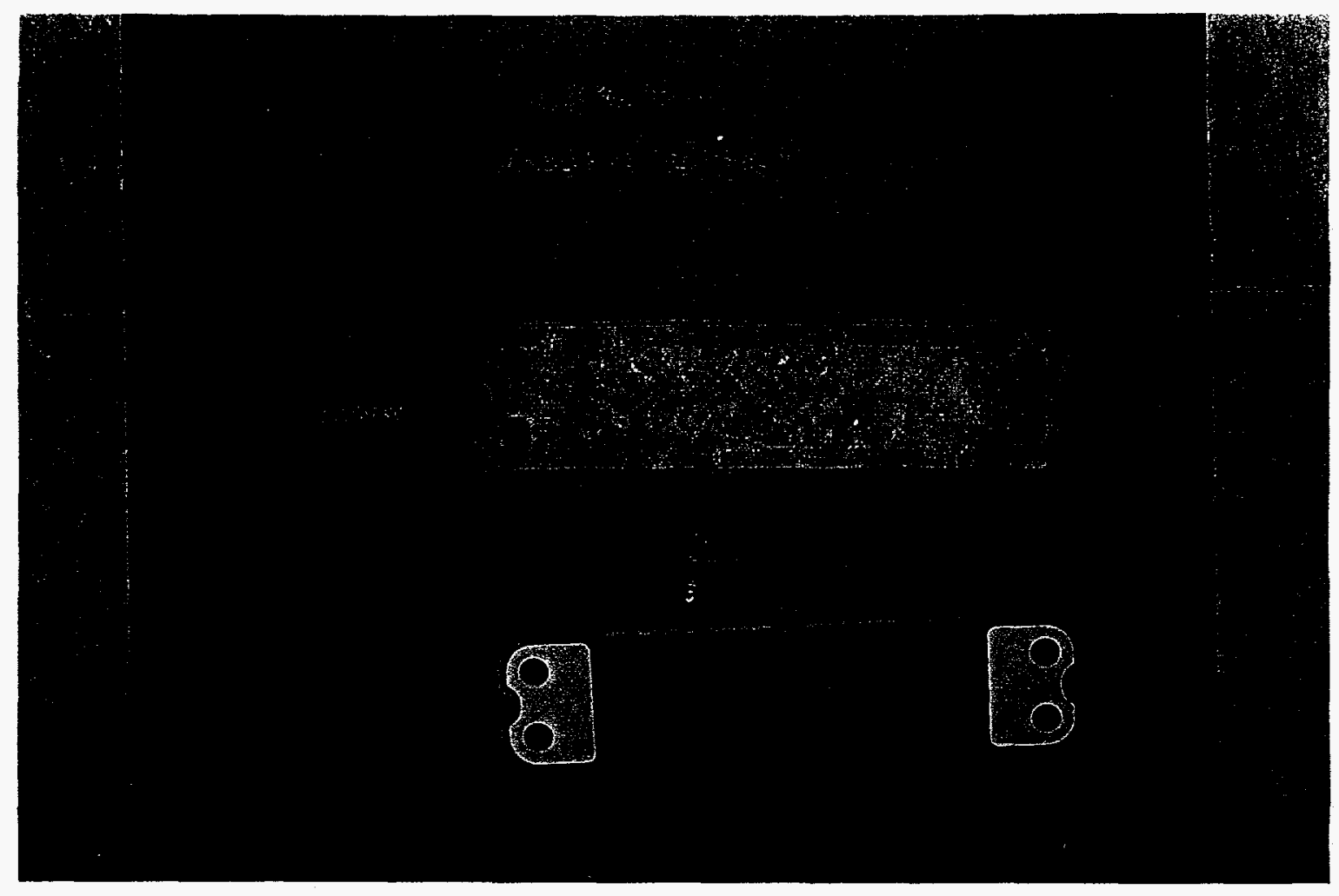


Appendix 6

Photographs from Platinised Ti Anode/Ni Cathode Run at end. 

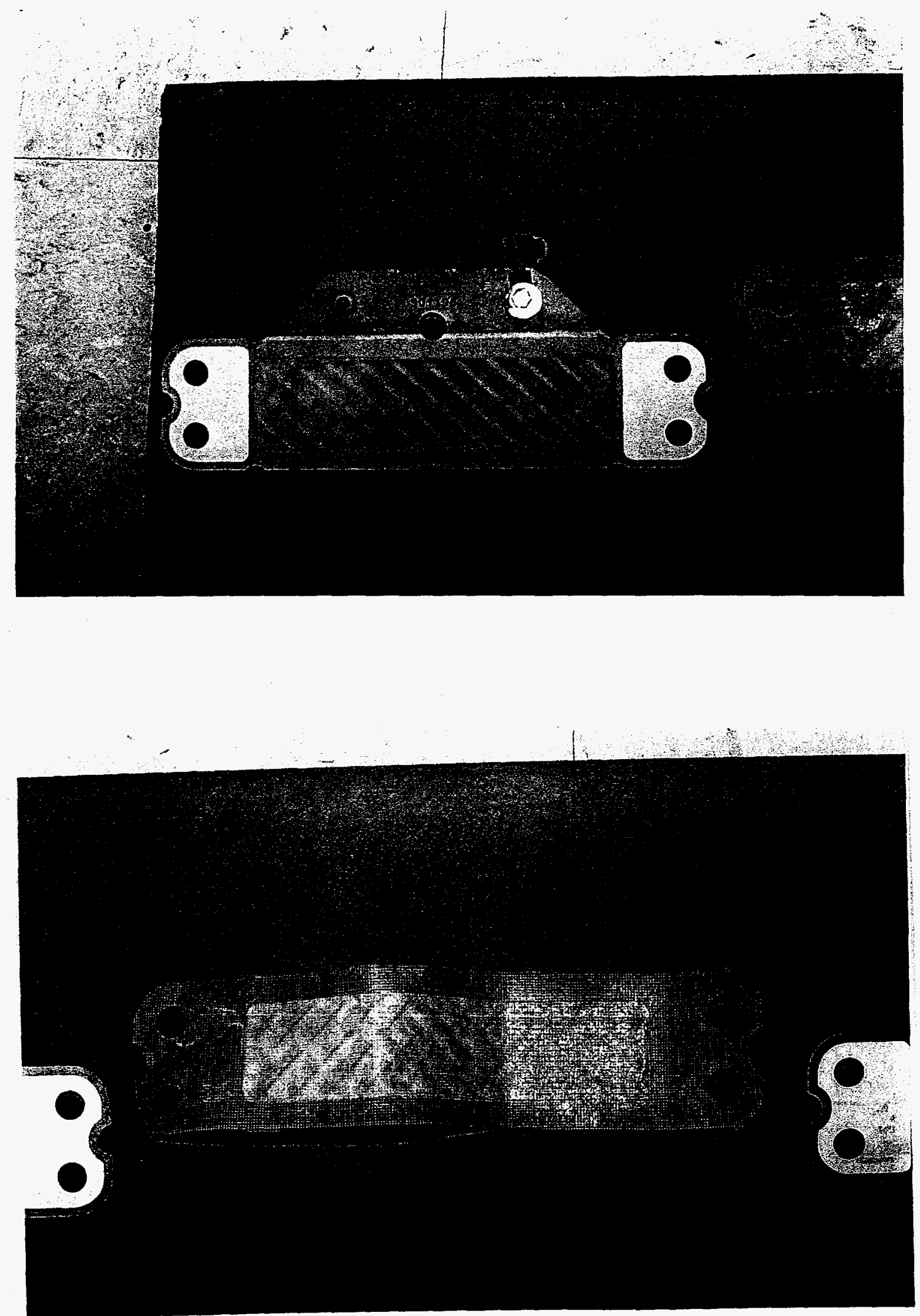


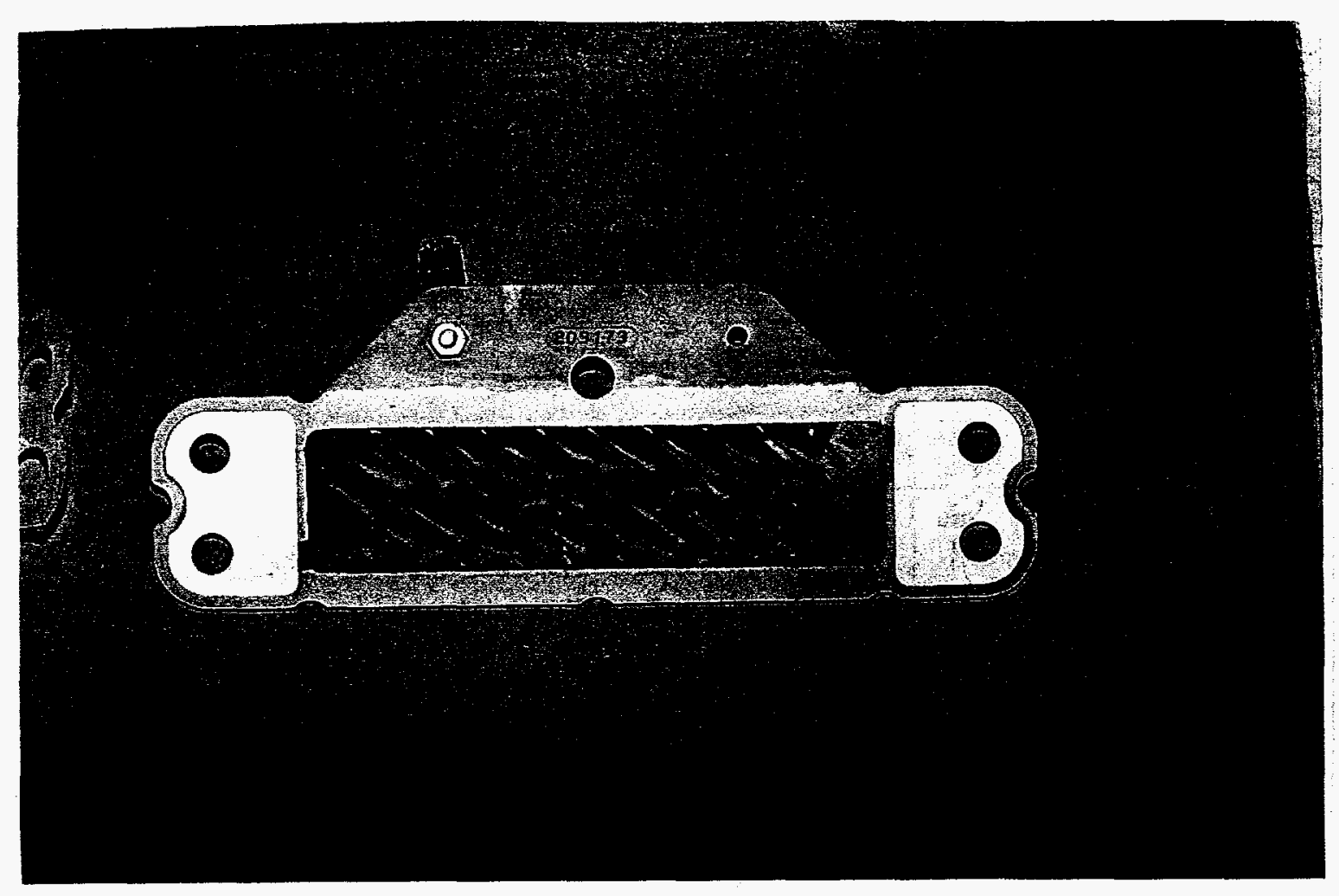

